\title{
Structural Characterization of the Lignin in the Cortex and Pith of Elephant Grass (Pennisetum purpureum) Stems
}

\author{
José C. del Río, ${ }^{* \dagger}{ }^{\dagger}$ Pepijn Prinsen, ${ }^{\dagger}$ Jorge Rencoret, ${ }^{\dagger \dagger}$ Lidia Nieto, ${ }^{\S}$ Jesús Jiménez-Barbero, ${ }^{\S}$ John Ralph, ${ }^{\ddagger}$ \\ Ángel T. Martínez, ${ }^{\S}$ and Ana Gutiérrez ${ }^{\dagger}$ \\ ${ }^{\dagger}$ Instituto de Recursos Naturales y Agrobiología de Sevilla (IRNAS), CSIC, PO Box 1052, E-41080 Seville, Spain \\ ${ }^{\ddagger}$ Departments of Biochemistry and Biological Systems Engineering, the Wisconsin Bioenergy Initiative, and the DOE Great Lakes \\ Bioenergy Research Center, University of Wisconsin, Madison, Wisconsin 53706, United States \\ ${ }^{\S}$ Centro de Investigaciones Biológicas (CIB), CSIC, Ramiro de Maeztu 9, E-28040 Madrid, Spain
}

ABSTRACT: The structure of the lignin in the cortex and pith of elephant grass (Pennisetum purpureum) stems was studied both in situ and in isolated milled "wood" lignins by several analytical methods. The presence of $p$-coumarate and ferulate in the cortex and pith, as well as in their isolated lignins, was revealed by pyrolysis in the presence of tetramethylammonium hydroxide, and by $2 \mathrm{D} \mathrm{NMR}$, and indicated that ferulate acylates the carbohydrates while $p$-coumarate acylates the lignin polymer. $2 \mathrm{D}$ NMR showed a predominance of alkyl aryl ether $\left(\beta-\mathrm{O}-4^{\prime}\right)$ linkages ( $82 \%$ of total interunit linkages), with low amounts of "condensed" substructures, such as resinols $\left(\beta-\beta^{\prime}\right)$, phenylcoumarans $\left(\beta-5^{\prime}\right)$, and spirodienones $\left(\beta-1^{\prime}\right)$. Moreover, the NMR also indicated that these lignins are extensively acylated at the $\gamma$-carbon of the side chain. DFRC analyses confirmed that p-coumarate groups acylate the $\gamma$-OHs of these lignins, and predominantly on syringyl units.

KEYWORDS: elephant grass, Pennisetum purpureum, cortex, pith, Py-GC/MS, TMAH, HSQC, DFRC, milled wood lignin, p-coumarate, ferulate, syringyl, guaiacyl

\section{INTRODUCTION}

Renewable sources of energy and consumer products are required for sustainable development of modern society. Plant biomass is the main source of renewable materials on Earth and represents a potential source of renewable energy and biobased products. The substitution of fossil fuels by biomass is an important contribution to reduce anthropogenic net $\mathrm{CO}_{2}$ emissions. Biomass is available in high amounts (as forest, agricultural or industrial lignocellulosic wastes and crops) at relatively low cost and could be a widely available and inexpensive source for biofuels and bioproducts in the near future. In this sense, there is a growing need to consider alternative agricultural strategies that move an agricultural industry focused on food production to one that also supplies the needs of other industrial sectors, such as pulp and paper, textiles, biofuels, or value-added chemicals, in the context of the so-called lignocellulose biorefinery. Biorefineries use renewable raw materials to produce energy together with a wide range of everyday commodities in an economic and sustainable manner. ${ }^{1,2}$ Therefore, significant efforts are being put into the search for highly productive biomass crops, including elephant grass.

Elephant grass (Pennisetum purpureum), also called Napier grass, is a species from the Poaceae native to the tropical grasslands of Africa and now introduced into most tropical and subtropical countries. It should not be confused with the species Miscanthus giganteus, also sometimes called elephant grass. The species is a robust grass with perennial stems, reaching over $3 \mathrm{~m}$ high, and is widely recognized as having the highest biomass productivity among herbaceous plants, attaining up to $45 \mathrm{Mg} \mathrm{ha}^{-1} \mathrm{y}^{-1,3,4}$ and therefore has been considered an excellent alternative feedstock to provide abundant and sustainable resources of lignocellulosic biomass for the production of biofuels. ${ }^{5}$

Cell wall polysaccharides can be used as feedstocks for the fermentative production of bioethanol or other biofuels after being broken down into simple sugars. However, in addition to cellulose, plant cell walls also contain more complex hemicellulosic polysaccharides, and an aromatic polymer, lignin, that hinders the degradation of cell wall polysaccharides to simple sugars. Therefore, the utilization of a specific energy crop for bioethanol production is strongly limited by its lignin content, composition, and structure. Biomass pretreatment is an essential step required to remove or modify the lignin to allow the access to, or isolation of, the plant cell wall polysaccharides for saccharification and eventual fermentation. Lignin is a heterogeneous and complex polymer synthesized mainly from three $p$-hydroxycinnamyl alcohols differing in their degree of methoxylation: $p$-coumaryl, coniferyl and sinapyl alcohols. Each of these monolignols gives rise to a different type of lignin unit called $p$-hydroxyphenyl $(\mathrm{H})$, guaiacyl $(\mathrm{G})$ and syringyl $(\mathrm{S})$ units, respectively, generating a variety of structures and linkages within the polymer. ${ }^{6-8}$ The lignin content, composition and structure vary widely among different plant species, among individuals, and even in different tissues of the same individual. The lignin composition greatly influences delignification reactions, and, therefore, structural characterization is an

Received: January 9, 2012

Revised: March 13, 2012

Accepted: March 14, 2012

Published: March 14, 2012 
essential step to develop appropriate methods to design effective lignin depolymerization strategies.

However, there is a lack of studies regarding the chemistry of the lignin of elephant grass. Previous papers have only reported the lignin contents of different cultivars of elephant grass and their variation with growth development, ${ }^{9}$ but did not provide any information about its composition and structure. In this paper, we therefore report the detailed chemical composition and structural characteristics of the lignin in elephant grass. For this purpose, the cortex and the pith of elephant grass stems were separated manually and analyzed independently by an array of analytical techniques. Among them, we used pyrolysisgas chromatography-mass spectrometry ( $\mathrm{Py}-\mathrm{GC} / \mathrm{MS})$, a rapid and highly sensitive technique for characterizing the chemical composition of lignin. ${ }^{10-13}$ However, the presence of $p$-hydroxycinnamates ( $p$-coumarate and ferulate), which are abundant in grasses, constitutes a complication for lignin analysis by analytical pyrolysis since they yield products similar to those of corresponding lignin units due to decarboxylation reactions. This problem can however be partially solved by using pyrolysis in the presence of tetramethylammonium hydroxide (TMAH), that avoids decarboxylation and releases intact (phenol- and acid-) methylated p-hydroxycinnamates. ${ }^{13,14}$ Additional information regarding the different units and interunit linkages present in the lignin polymer was provided by $2 \mathrm{D}$ NMR spectroscopy, which provides information of the structure of the whole macromolecule and is a powerful tool for lignin structural characterization, ${ }^{15-29}$ and DFRC (derivatization followed by reductive cleavage), which provides a measure of the monomer composition of lignins and gives information on the nature and extent of $\gamma$-acylation of the lignin side chain. ${ }^{26,30-35}$ The knowledge of the composition and structure of the lignin of elephant grass will help to maximize the exploitation of this interesting crop for biomass and biofuel production.

\section{MATERIALS AND METHODS}

Samples. Elephant grass (P. purpureum), cultivar "Paraiso", was collected at an age of 150 days old, from the experimental station of the University of Viçosa (Brazil). Elephant grass stems were air-dried and subsequently separated into the cortex and pith fractions. The dried samples were milled using a knife mill and successively extracted with acetone in a Soxhlet apparatus for $8 \mathrm{~h}$, and with hot water $(3 \mathrm{~h}$ at $100{ }^{\circ} \mathrm{C}$ ). The water-soluble material was lyophilized and then weighed to determine its content, while the total acetone extractives once weighed were redissolved in chloroform to separate the lipophilics from the polars, which were also weighed. Klason lignin content was estimated as the residue after sulfuric acid hydrolysis of the preextracted material according to Tappi test method T222 om- $88 .{ }^{36}$ The Klason lignin content was then corrected for proteins, determined from the $\mathrm{N}$ content by the Kjeldahl method using a 6.25 factor, ${ }^{37}$ and ash (determined as indicated below for the whole samples). The acidsoluble lignin was determined, after the insoluble lignin was filtered off, by UV-spectroscopic determination at $205 \mathrm{~nm}$ wavelength using $110 \mathrm{~L}$ $\mathrm{cm}^{-1} \mathrm{~g}^{-1}$ as the extinction coefficient. Holocellulose was isolated from the pre-extracted fibers by delignification for $4 \mathrm{~h}$ using the acid chlorite method. ${ }^{38}$ The $\alpha$-cellulose content was determined by removing the hemicelluloses from the holocellulose by alkali extraction. ${ }^{38}$ Ash content was estimated as the residue after $6 \mathrm{~h}$ of heating at $575{ }^{\circ} \mathrm{C}$. Three replicates were used for each sample.

"Milled-Wood Lignin" (MWL) Isolation. The MWLs were obtained according to the classical procedure. ${ }^{39}$ Extractivefree ground cortex and pith samples (prepared as above) were finely ball-milled in a Retsch PM100 planetary mill (40 h at $400 \mathrm{rpm}$ for $25 \mathrm{~g}$ of wood) using a $500 \mathrm{~mL}$ agate jar and agate ball bearings $(20 \times 20 \mathrm{~mm})$, and toluene as coolant. The milled samples were submitted to an extraction $(3 \times 12 \mathrm{~h})$ with dioxane:water $(9: 1, \mathrm{v} / \mathrm{v})$
(20 $\mathrm{mL}$ solvent/g milled sample). The suspension was centrifuged and the supernatant evaporated at $40{ }^{\circ} \mathrm{C}$ under reduced pressure. The residue obtained (raw MWL, $1.765 \mathrm{~g}$ ) was redissolved in acetic acid/ water 9:1 (v/v) (25 mL solvent/g raw MWL). The solution was then precipitated into stirred cold water, and the residue was separated by centrifugation, milled in an agate mortar and dissolved in 1,2dichloroethane:ethanol $(2: 1, \mathrm{v} / \mathrm{v})$. The mixture was then centrifuged to eliminate the insoluble material. The resulting supernatant was precipitated into cold diethyl ether, centrifuged, and subsequently resuspended in $30 \mathrm{~mL}$ of petroleum ether and centrifuged again to obtain the purified MWL, which was dried under a current of $\mathrm{N}_{2}$. The final yields ranged from 15 to $20 \%$ based on the Klason lignin content.

Gel Permeation Chromatography (GPC). GPC analyses of the isolated MWLs were performed on a Shimadzu LC-20A LC system (Shimadzu, Kyoto, Japan) equipped with a photodiode array (PDA) detector (SPD-M20A; Shimadzu) using the following conditions: TSK gel $\alpha-\mathrm{M}+\alpha-2500$ (Tosoh, Tokyo, Japan) column; $0.1 \mathrm{M} \mathrm{LiBr}$ in dimethylformamide (DMF) as eluent; $0.5 \mathrm{~mL} \mathrm{~min}^{-1}$ flow rate; $40{ }^{\circ} \mathrm{C}$ oven temperature; PDA detection at $280 \mathrm{~nm}$. The data acquisition and computation used LCsolution version 1.25 software (Shimadzu). The molecular weight calibration was via polystyrene standards.

Analytical Pyrolysis. Pyrolysis of the elephant grass stem cortex and pith fractions and their isolated MWL samples (approximately $100 \mu \mathrm{g}$ ) were performed with a 2020 microfurnace pyrolyzer (Frontier Laboratories Ltd.) connected to an Agilent 6890 GC/MS system equipped with a DB-1701 fused-silica capillary column $(30 \mathrm{~m} \times$ $0.25 \mathrm{~mm}$ i.d., $0.25 \mu \mathrm{m}$ film thickness) and an Agilent 5973 mass selective detector (EI at $70 \mathrm{eV}$ ). The pyrolysis was performed at $500{ }^{\circ} \mathrm{C}$. The GC oven temperature was programmed from $50{ }^{\circ} \mathrm{C}$ $(1 \mathrm{~min})$ to 100 at $30^{\circ} \mathrm{C} \mathrm{min}^{-1}$ and then to $290^{\circ} \mathrm{C}(10 \mathrm{~min})$ at $6{ }^{\circ} \mathrm{C}$ $\mathrm{min}^{-1}$. Helium was the carrier gas $\left(1 \mathrm{~mL} \mathrm{~min}^{-1}\right)$. For Py/TMAH, $100 \mu \mathrm{g}$ of sample was mixed with approximately $0.5 \mu \mathrm{L}$ of TMAH $(25 \%, \mathrm{w} / \mathrm{w}$, in methanol) and the pyrolysis was carried out as described above. The compounds were identified by comparing their mass spectra with those of the Wiley and NIST libraries and those reported in the literature. ${ }^{10,11}$ Peak molar areas were calculated for the released pyrolysis products, the summed areas were normalized, and the data for two repetitive analyses were averaged and expressed as percentages.

NMR Spectroscopy. For the NMR of the whole cell walls, around $100 \mathrm{mg}$ of finely divided (ball-milled) extractive-free samples was swollen in $0.75 \mathrm{~mL}$ of DMSO- $d_{6}$ according to the method previously described. ${ }^{21,24}$ In the case of the isolated MWLs, around $40 \mathrm{mg}$ was dissolved in $0.75 \mathrm{~mL}$ of DMSO- $d_{6}$. NMR spectra were recorded at $25{ }^{\circ} \mathrm{C}$ on a Bruker AVANCE $600 \mathrm{MHz}$ instrument equipped with a cryogenically cooled $z$-gradient triple-resonance probe. HSQC (heteronuclear single quantum coherence) experiments used Bruker's "hsqcetgp" pulse program with spectral widths of 5000 and $13200 \mathrm{~Hz}$ for the ${ }^{1} \mathrm{H}$ and ${ }^{13} \mathrm{C}$ dimensions. The number of collected complex points was 2048 for the ${ }^{1} \mathrm{H}$ dimension with a recycle delay of $1 \mathrm{~s}$. The number of transients was 64, and 256 time increments were recorded in the ${ }^{13} \mathrm{C}$ dimension. The ${ }^{1} J_{\mathrm{CH}}$ used was $140 \mathrm{~Hz}$. Processing used typical matched Gaussian apodization in ${ }^{1} \mathrm{H}$ and a squared cosine-bell in ${ }^{13} \mathrm{C}$. Prior to Fourier transformation, the data matrices were zerofilled up to 1024 points in the ${ }^{13} \mathrm{C}$ dimension. The central solvent peak was used as an internal reference $\left(\delta_{\mathrm{C}} 39.5 ; \delta_{\mathrm{H}} 2.49\right)$. HSQC crosssignals were assigned by comparison with the literature. ${ }^{15-29} \mathrm{~A}$ semiquantitative analysis of the volume integrals of the HSQC crosscorrelation signals was performed. As the volume integral depends on the particular ${ }^{1} J_{\mathrm{CH}}$ value, as well on the $T_{2}$ relaxation time, absolute quantitation is impossible but relative integrals (between spectra) allow valid comparisons. Thus, the integration of the cross-signals was performed separately for the different regions of the HSQC spectrum, which contain signals that correspond to chemically analogous carbon-proton pairs. For these signals, the ${ }^{1} J_{\mathrm{CH}}$ coupling value is similar and integrals can be used semiquantitatively to estimate the relative abundance of the different species. In the aliphatic oxygenated region, the relative abundances of side chains involved in interunit linkages or present in terminal units were estimated from the $\mathrm{C}_{\alpha}-\mathrm{H}_{\alpha}$ correlations to avoid possible interference from homonuclear ${ }^{1} \mathrm{H}-{ }^{1} \mathrm{H}$ 
couplings, except for substructures $\mathbf{E}$ and $\mathbf{I} / \mathbf{I}^{\prime}$, for which $\mathrm{C}_{\beta}-\mathrm{H}_{\beta}$ and $\mathrm{C}_{\gamma}-\mathrm{H}_{\gamma}$ correlations were used. In the aromatic region, $\mathrm{C}_{2}-\mathrm{H}_{2}$ correlations from $\mathrm{H}, \mathrm{G}$ and $\mathrm{S}$ lignin units and from $p$-coumarate and ferulate were used to estimate their relative abundances.

DFRC (Derivatization Followed by Reductive Cleavage). The DFRC degradation was performed according to the developed protocol. ${ }^{30-33}$ Lignins $(10 \mathrm{mg})$ were stirred for two hours at $50{ }^{\circ} \mathrm{C}$ with acetyl bromide in acetic acid (8:92). The solvents and excess acetyl bromide were removed by rotary evaporation at reduced pressure. The products were then dissolved in dioxane/acetic acid/ water $(5: 4: 1, \mathrm{v} / \mathrm{v} / \mathrm{v})$, and $50 \mathrm{mg}$ of powdered $\mathrm{Zn}$ was added. After 40 min of stirring at room temperature, the mixture was transferred into a separatory funnel with dichloromethane and saturated ammonium chloride. The $\mathrm{pH}$ of the aqueous phase was adjusted to less than 3 by adding $3 \% \mathrm{HCl}$, the mixture vigorously mixed and the organic layer separated. The water phase was extracted twice more with dichloromethane. The combined dichloromethane fractions were dried over anhydrous $\mathrm{Na}_{2} \mathrm{SO}_{4}$, and the filtrate was evaporated on a rotary evaporator. The residue was acetylated for $1 \mathrm{~h}$ in $1.1 \mathrm{~mL}$ of dichloromethane containing $0.2 \mathrm{~mL}$ of acetic anhydride and $0.2 \mathrm{~mL}$ of pyridine. The acetylated lignin degradation products were collected after rotary evaporation of the solvents and subsequently analyzed by GC/MS using mass spectra and relative retention times to authenticate the DFRC monomers and their $p$-coumarate conjugates as described. ${ }^{30-33}$ To assess the presence of naturally acetylated lignin units, the described modification of the standard DFRC method using propionylating instead of acetylating reagents (DFRC') was used in the present study. ${ }^{26,34,35}$

The GC/MS analyses were performed with a GCMS-QP2010plus instrument (Shimadzu Co.) using a capillary column (SHR5XLB $30 \mathrm{~m} \times 0.25 \mathrm{~mm}$ i.d., $0.25 \mu \mathrm{m}$ film thickness). The oven was heated from $140{ }^{\circ} \mathrm{C}(1 \mathrm{~min})$ to 250 at $3{ }^{\circ} \mathrm{C} / \mathrm{min}^{-1}$, then ramped at $10{ }^{\circ} \mathrm{C} / \mathrm{min}^{-1}$ to $280{ }^{\circ} \mathrm{C}(1 \mathrm{~min})$ and finally ramped at $20{ }^{\circ} \mathrm{C} / \mathrm{min}^{-1}$ to $300{ }^{\circ} \mathrm{C}$, and held for $18 \mathrm{~min}$ at the final temperature. The injector was set at $250{ }^{\circ} \mathrm{C}$, and the transfer line was kept at $310^{\circ} \mathrm{C}$. Helium was used as the carrier gas at a rate of $1 \mathrm{~mL} / \mathrm{min}^{-1}$. Quantitation of the released individual monomers was performed using 4,4'-ethylenebisphenol as internal standard. Molar yields were calculated on the basis of molecular weights of the respective acetylated and/or propionylated compounds.

\section{RESULTS AND DISCUSSION}

In this work, we separated the cortex (84\%) and the pith (16\%) fractions of the stem and studied them independently. The abundance of the main constituents (namely, water-soluble material, acetone extractives, Klason lignin, acid-soluble lignin, holocellulose, $\alpha$-cellulose, and ash) of the cortex and pith are shown in Table 1. The lignin content differs in each fraction of

Table 1. Abundance of the Main Constituents (\% dry weight) of Elephant Grass (P. purpureum) Fractions

\begin{tabular}{lcc} 
& elephant grass cortex & elephant grass pith \\
\% of whole material & 84 & 16 \\
water-soluble material & $8.8 \pm 0.4$ & $10.4 \pm 0.1$ \\
acetone extractives & $1.7 \pm 0.4$ & $2.3 \pm 0.2$ \\
Klason lignin & $18.5 \pm 0.6$ & $15.5 \pm 1.0$ \\
acid-soluble lignin & $1.5 \pm 0.1$ & $1.6 \pm 0.1$ \\
holocellulose $(\alpha$-cellulose $)$ & $64.1 \pm 1.7$ & $59.7 \pm 0.5$ \\
& $(40.0 \pm 1.4)$ & $(46.4 \pm 3.4)$ \\
ash & $5.4 \pm 0.2$ & $10.5 \pm 1.5$ \\
\hline
\end{tabular}

the elephant grass stem, with the cortex having higher lignin content (18.5\% Klason lignin) than the pith (15.5\%). The compositions of the lignin in both parts of the elephant grass were analyzed in situ by $\mathrm{Py}-\mathrm{GC} / \mathrm{MS}$ and $2 \mathrm{D}$ NMR. Additionally, for a more detailed structural characterization, the MWLs were isolated by aqueous dioxane extraction from finely ball-milled samples according to the classical lignin isolation procedure ${ }^{39}$ and subsequently analyzed by $\mathrm{Py}-\mathrm{GC} / \mathrm{MS}$, 2D NMR and DFRC, and the molecular weights estimated by GPC.

Molecular Weight Distributions. The values of the weight-average $\left(M_{\mathrm{w}}\right)$ and number-average $\left(M_{\mathrm{n}}\right)$ molecular weights of the MWL isolated from the cortex and pith fractions of elephant grass stems, estimated from the GPC curves (relative values related to polystyrene standards), and the polydispersity $\left(M_{\mathrm{w}} / M_{\mathrm{n}}\right)$, are indicated in Table 2 . The two lignins exhibited

Table 2. Weight-Average $\left(M_{w}\right)$ and Number-Average $\left(M_{n}\right)$ Molecular Weights $\left(\mathrm{g} \mathrm{mol}^{-1}\right)$, and Polydispersity $\left(M_{\mathrm{w}} / M_{\mathrm{n}}\right)$ of the MWLs Isolated from the Cortex and Pith of Elephant Grass (P. purpureum)

$\begin{array}{lcc} & \text { MWL cortex } & \text { MWL pith } \\ M_{\mathrm{w}} & 6920 & 6720 \\ M_{\mathrm{n}} & 2390 & 2490 \\ M_{\mathrm{w}} / M_{\mathrm{n}} & 2.9 & 2.7\end{array}$

similar molecular weight distributions, in the range 6920-6720 g $\mathrm{mol}^{-1}$, being slightly higher in the case of the lignin from the cortex. In addition, both lignins exhibited relatively narrow molecular weight distributions, with $M_{\mathrm{w}} / M_{\mathrm{n}}<3$. Those values are comparable to literature values for various isolated lignins. ${ }^{28,29,40}$

Py-GC/MS. The pyrograms of the cortex and pith of elephant grass, and of their corresponding MWLs, are shown in Figure 1. The identities and relative molar abundances of the released compounds are listed in Table 3. Pyrolysis of the whole cell walls of cortex and pith (Figures $1 \mathrm{a}$ and $1 \mathrm{~b}$ ) released compounds from the carbohydrate and lignin moieties, as well as from $p$-hydroxycinnamates. Among the carbohydrate-derived compounds, the main ones were 2-methylfuran (1), hydroxyacetaldehyde (2), (3H)-furan-2-one (4), propanal (5), furfural (7), $(5 \mathrm{H})$-furan-2-one (12) and 2-hydroxy-3-methyl-2-cyclopenten1-one (18). Among the lignin derived phenols, the pyrograms of the cortex and pith showed compounds derived from p-hydroxyphenyl $(\mathrm{H})$, guaiacyl $(\mathrm{G})$ and syringyl $(\mathrm{S})$ lignin units as well as from the cinnamic acid esters in the wall. The most prominent cinnamate or lignin-derived compounds released were 4-vinylphenol (27) and 4-vinylguaiacol (30), with important amounts of other lignin-derived compounds such as phenol (16), guaiacol (21), syringol (33) and 4-vinylsyringol (44). However, the high amounts of 4-vinylphenol released upon pyrolysis from these samples, as in other grasses, is mostly due to the presence of $p$-coumarates, as will be shown below, which decarboxylates efficiently under pyrolytic conditions. ${ }^{13,14}$ Similarly, 4-vinylguaiacol, which is present in high abundance among the pyrolysis products of the whole cell walls, also arises from ferulate after decarboxylation upon pyrolysis. Therefore, it is obvious that these vinyl compounds cannot be used for the estimation of the lignin $\mathrm{H}: \mathrm{G}: \mathrm{S}$ composition upon $\mathrm{Py}-\mathrm{GC} / \mathrm{MS}$ as the major part of them do not arise from the core lignin structural units but from $p$-hydroxycinnamates that are either not associated with the lignin structure (ferulates on arabinoxylans) or only partially ( $p$-coumarates on arabinoxylans, but also acylating lignin side chains). A rough estimation of the $\mathrm{S} / \mathrm{G}$ ratio can be obtained (by using the molar areas of all the G- and S-derived compounds, except 4-vinylguaiacol, that also arises from ferulates, and its respective 4-vinylsyringol), being 1.2 in both cortex and pith.

Pyrolysis of the MWLs isolated from the cortex and pith of elephant grass stems (Figures $1 \mathrm{c}$ and 1d) released a similar 

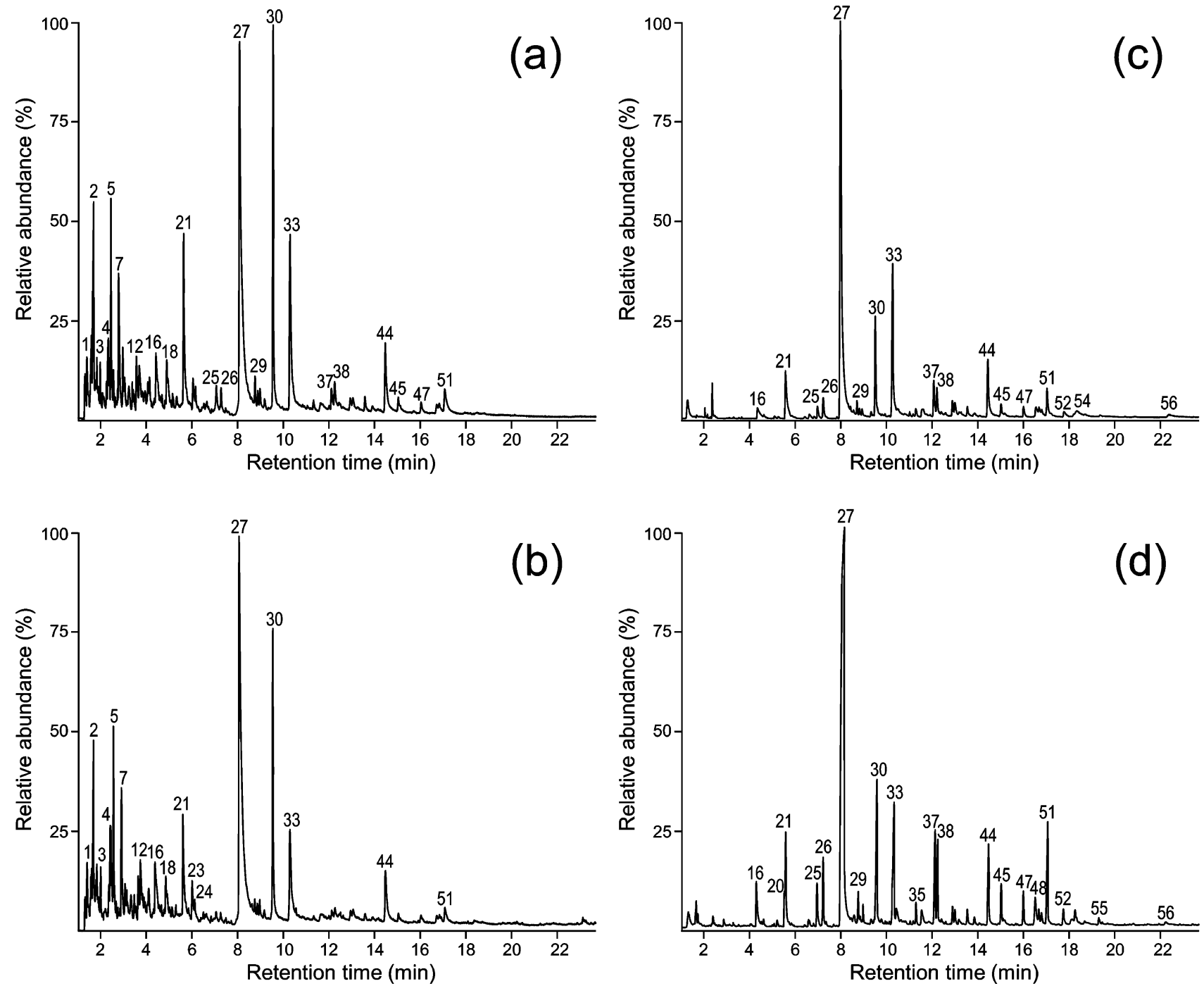

Figure 1. Py-GC/MS chromatograms of elephant grass (P. purpureum) cortex (a) and pith (b), and the MWLs isolated from cortex (c) and pith (d). The identities and relative abundances of the released numbered compounds are listed in Table 3.

distribution of cinnamate- and lignin-derived compounds as from their respective whole cell walls, except for the much lower relative abundance of 4-vinylguaiacol (30). The most prominent compound in the pyrograms of the MWLs was still 4-vinylphenol (27), derived largely from the $p$-coumarate esters acylating lignin side chains (see later), and as also occurred in the pyrolysis of their whole cell walls. The estimation of the $\mathrm{S} / \mathrm{G}$ ratios (by ignoring the respective vinyl compounds) was 1.5 and 1.4 in the MWL of the cortex and pith, suggesting that syringyl-rich oligomers were slightly preferentially extracted into the MWL fraction. The similarity with the lignin $S / G$ ratios observed in the whole cell walls reveals the importance of excluding the vinyl compounds for calculation, at least in grasses, where $p$-hydroxycinnamates are important components.

It is clear then that $p$-hydroxycinnamic acids, which form linkages with lignin and/or carbohydrates in plants, and are particularly abundant in grasses, ${ }^{13,41-48}$ interferes in the estimation of the lignin composition which cannot, therefore, be evaluated properly by conventional pyrolysis. The presence of $p$-hydroxycinnamates in the whole cell walls, as well as in the isolated lignins, however, could be addressed by pyrolysis in the presence of a methylating agent, tetramethylammonium hydroxide (TMAH), that efficiently prevents decarboxylation and results in transesterification (producing methyl esters, as well as methylating the phenol), ${ }^{13,14}$ as shown in Figure 2. The identities of the compounds released and their relative molar abundances are listed in Table 4. Py/TMAH induces cleavage of alkyl aryl ether bonds in lignin and releases products similar to those obtained upon $\mathrm{CuO}$ alkaline degradation, including methylated hydroxybenzaldehydes (peaks 6, 12 and 18), hydroxyacetophenones (peaks 15 and 22) and hydroxybenzoic acids (peaks 10, 16 and 24). ${ }^{13,14,49,50}$ As seen in Figure 2, Py/TMAH of the cortex and pith released high amounts (over $45 \%$ of the total peak area) of the fully methylated derivative of $p$-coumaric acid, i.e., trans-3-(4-methoxyphenyl)propenoic acid methyl ester, or methyl trans-4-O-methyl-p-coumarate (peak 23 ), as well as lower amounts (nearly $5 \%$ of total peak area) of the fully methylated derivative of ferulic acid, i.e., trans-3-(3,4dimethoxyphenyl)propenoic acid methyl ester, or methyl 4-O-methyl-ferulate (peak 29). In addition to the trans-forms of methylated $p$-hydroxycinnamic acids, minor amounts of the cis-isomers (peaks 17 and 26) were also identified. These TMAH transesterification and methylation products clearly establish that the high amounts of 4-vinylphenol and 4-vinylguaiacol released upon $\mathrm{Py}-\mathrm{GC} / \mathrm{MS}$ of the cell wall and lignin samples arise mainly from $p$-coumarate and ferulate esters in the wall, and not from 
Table 3. Identities and Relative Molar Abundances of the Compounds Released after Py-GC/MS of Elephant Grass (P. purpureum) Cortex and Pith and Their Isolated MWLs

\begin{tabular}{|c|c|c|c|c|c|c|}
\hline label & & origin $^{a}$ & cortex & MWL cortex & pith & MWL pith \\
\hline 1 & 2-methylfuran & PS & 2.3 & 0.0 & 1.2 & 0.0 \\
\hline 2 & hydroxyacetaldehyde & PS & 9.1 & 0.0 & 7.9 & 0.0 \\
\hline 3 & 3-hydroxypropanal & PS & 0.7 & 0.0 & 1.2 & 0.0 \\
\hline 4 & $(3 \mathrm{H})$-furan-2-one & PS & 0.8 & 0.0 & 1.2 & 0.0 \\
\hline 5 & propanal & PS & 6.7 & 0.0 & 7.8 & 0.0 \\
\hline 6 & $(2 \mathrm{H})$-furan-3-one & PS & 0.8 & 0.0 & 0.6 & 0.0 \\
\hline 7 & furfural & PS & 4.9 & 0.0 & 4.9 & 0.0 \\
\hline 8 & 4-methyltetrahydrofuran-3-one & PS & 0.9 & 0.0 & 0.5 & 0.0 \\
\hline 9 & 1-acetoxypyran-3-one & PS & 0.4 & 0.0 & 0.3 & 0.0 \\
\hline 10 & 2-hydroxymethylfuran & PS & 0.4 & 0.0 & 0.3 & 0.0 \\
\hline 11 & cyclopent-1-ene-3,4-dione & PS & 1.2 & 0.0 & 1.2 & 0.0 \\
\hline 12 & $(5 H)$-furan-2-one & PS & 2.4 & 0.0 & 1.9 & 0.0 \\
\hline 13 & 2,3-dihydro-5-methylfuran-2-one & PS & 1.8 & 0.0 & 2.6 & 0.0 \\
\hline 14 & 2-acetylfuran & PS & 0.6 & 0.0 & 0.5 & 0.0 \\
\hline 15 & 2-methyl-2-cyclopenten-1-one & PS & 1.0 & 0.0 & 0.5 & 0.0 \\
\hline 16 & phenol & $\mathrm{LH}$ & 3.1 & 2.3 & 4.1 & 3.9 \\
\hline 17 & 4-hydroxy-5,6-dihydro-( $2 H)$-pyran-2-one & PS & 0.2 & 0.0 & 0.3 & 0.0 \\
\hline 18 & 2-hydroxy-3-methyl-2-cyclopenten-1-one & PS & 2.3 & 0.0 & 2.1 & 0.0 \\
\hline 19 & 4-hydroxybenzaldehyde & PS & 0.4 & 0.0 & 0.3 & 0.0 \\
\hline 20 & methylphenol & LH & 0.4 & 1.3 & 0.3 & 3.1 \\
\hline 21 & guaiacol & LG & 4.4 & 4.4 & 3.0 & 3.0 \\
\hline 22 & methylphenol & $\mathrm{LH}$ & 1.3 & 0.0 & 1.3 & 0.0 \\
\hline 23 & anhydro sugar & PS & 0.8 & 0.0 & 1.2 & 0.0 \\
\hline 24 & 2-hydroxy-3-ethyl-2-cyclopenten-1-one & PS & 0.5 & 0.0 & 0.6 & 0.0 \\
\hline 25 & C2-phenol & $\mathrm{LH}$ & 1.0 & 1.0 & 0.5 & 2.4 \\
\hline 26 & 4-methylguaiacol & LG & 0.6 & 1.4 & 0.4 & 2.7 \\
\hline 27 & 4-vinylphenol & LH/PCA & 27.2 & 54.8 & 33.9 & 45.3 \\
\hline 28 & 4-allylphenol & $\mathrm{LH}$ & 0.0 & 0.1 & 0.0 & 0.1 \\
\hline 29 & 4-ethylguaiacol & LG & 0.5 & 0.5 & 0.3 & 1.0 \\
\hline 30 & 4-vinylguaiacol & LG/FA & 7.3 & 5.0 & 7.3 & 6.6 \\
\hline 31 & cis-4-propenylphenol & $\mathrm{LH}$ & 0.0 & 0.1 & 0.0 & 0.1 \\
\hline 32 & eugenol & LG & 0.2 & 0.5 & 0.2 & 0.7 \\
\hline 33 & syringol & LS & 6.8 & 9.9 & 4.6 & 6.4 \\
\hline 34 & trans-4-propenylphenol & $\mathrm{LH}$ & 0.0 & 0.6 & 0.0 & 1.1 \\
\hline 35 & cis-isoeugenol & LG & 0.2 & 0.5 & 0.2 & 0.7 \\
\hline 36 & vanillin & LG & 0.7 & 1.0 & 0.7 & 1.1 \\
\hline 37 & 4-methylsyringol & LS & 0.6 & 2.1 & 0.3 & 3.5 \\
\hline 38 & trans-isoeugenol & LG & 0.7 & 1.4 & 0.4 & 2.6 \\
\hline 39 & 4-propinylguaiacol & LG & 0.3 & 0.9 & 0.3 & 0.7 \\
\hline 40 & 4-allenylguaiacol & LG & 0.3 & 0.8 & 0.4 & 0.5 \\
\hline 41 & acetoguaiacone & LG & 0.1 & 0.2 & 0.1 & 0.3 \\
\hline 42 & 4-ethylsyringol & LS & 0.4 & 0.5 & 0.2 & 0.6 \\
\hline 43 & guaiacyl acetone & LG & 0.2 & 0.3 & 0.2 & 0.3 \\
\hline 44 & 4-vinylsyringol & LS & 2.5 & 3.7 & 2.4 & 3.1 \\
\hline 45 & 4-allylsyringol & LS & 0.4 & 0.6 & 0.2 & 1.2 \\
\hline 46 & 4-propylsyringol & LS & 0.1 & 0.1 & 0.1 & 0.1 \\
\hline 47 & cis-4-propenylsyringol & LS & 0.4 & 0.6 & 0.3 & 1.0 \\
\hline 48 & syringaldehyde & LS & 0.3 & 0.8 & 0.3 & 1.5 \\
\hline 49 & 4-propinylsyringol & LS & 0.2 & 0.3 & 0.2 & 0.3 \\
\hline 50 & 4-allenylsyringol & LS & 0.2 & 0.2 & 0.2 & 0.3 \\
\hline 51 & trans-propenylsyringol & LS & 1.2 & 1.6 & 0.7 & 3.5 \\
\hline 52 & acetosyringone & LS & 0.1 & 0.5 & 0.0 & 0.8 \\
\hline 53 & trans-coniferaldehyde & LG & 0.0 & 0.3 & 0.0 & 0.4 \\
\hline 54 & syringylacetone & LS & 0.1 & 1.0 & 0.2 & 0.7 \\
\hline 55 & propiosyringone & LS & 0.0 & 0.1 & 0.0 & 0.3 \\
\hline \multirow[t]{2}{*}{56} & trans-sinapaldehyde & LS & 0.0 & 0.6 & 0.0 & 0.2 \\
\hline & & $S / G$ ratio $^{b}$ & 1.2 & 1.5 & 1.2 & 1.4 \\
\hline
\end{tabular}

${ }^{a}$ PS: polysaccharide. LH: lignin $p$-hydroxyphenyl-type. LG: lignin guaiacyl-type. LS: lignin syringyl-type. PCA: $p$-coumarate. FA: ferulate. ${ }^{b}$ All G- and $\mathrm{S}$-derived peaks were used for the estimation of the $\mathrm{S} / \mathrm{G}$ ratio, except 4-vinylguaiacol (arising from ferulates), and the analogous 4-vinylsyringol. 

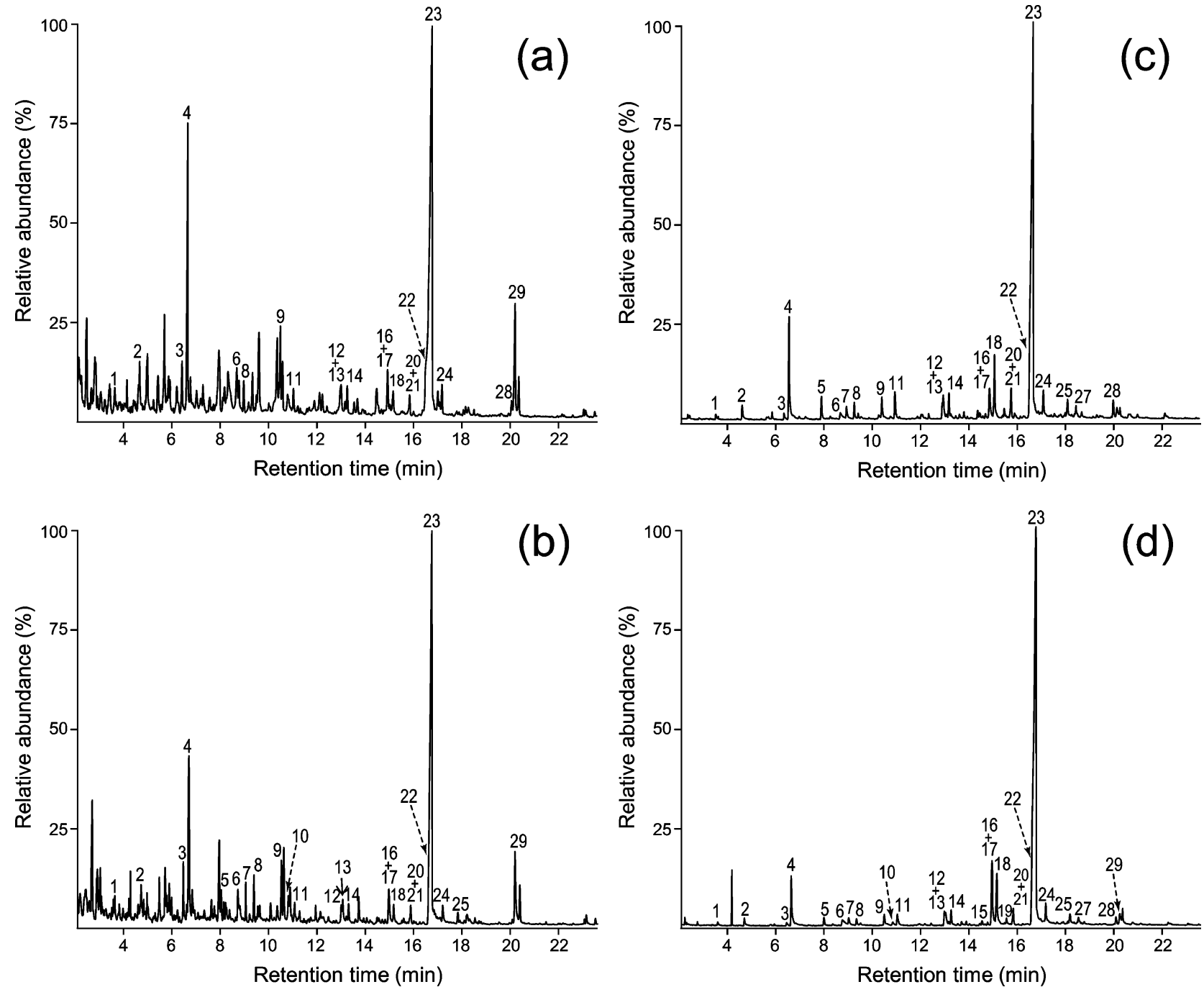

Figure 2. Py-TMAH-GC/MS chromatograms of elephant grass (P. purpureum) cortex (a) and pith (b), and the MWLs isolated from cortex (c) and pith (d). The identities and relative abundances of the numbered released compounds are listed in Table 4. [Note that the compound numbers are not the same as those in Figure 1 and Table 3.]

the core lignin itself, highlighting the fact that these two vinyl products cannot be used in the estimate of lignin composition from pyrolysis. Unfortunately, these components have been used in $\mathrm{H}: \mathrm{G}: S$ determinations in the past, but this practice must cease: the $H: G: S$ ratio of lignins refers (or should refer!) strictly to the composition of the core lignin that arises from polymerization of the $\mathrm{H}, \mathrm{G}$, and $\mathrm{S}$ monolignols, namely, $p$-coumaryl, coniferyl, and sinapyl alcohols.

The relative abundances of $p$-hydroxycinnamates ( $p$-coumarate) ferulate ratio) present in the cortex and pith and in their isolated lignins were estimated by Py/TMAH (Table 4) and revealed additional features. Both $p$-coumarate and ferulate were found in the whole cell walls of the cortex and pith, while only $p$-coumarate and essentially no ferulate (only trace amounts, $\sim 1 \%)$ was found in the isolated lignins. This indicates, as has been known for a long time in grasses, ${ }^{41-48}$ that, in the cortex and pith of elephant grass, ferulate is mostly attached to the carbohydrates while $p$-coumarate is primarily attached to the lignin polymer. Studies on different plants, including other grasses, have indicated that $p$-coumarate acylates the $\gamma-\mathrm{OH}$ of lignin side chains, and predominantly on $S$ units. ${ }^{26,33,41,43,47,48,51,52}$ Therefore, the major part of the $p$-coumarate present in the lignin of the cortex and pith of elephant grass was hypothesized to also acylate the $\gamma-\mathrm{OH}$ of the lignin side chain, as will be validated below.

2D NMR. The whole cell walls of the elephant grass cortex and pith fractions were analyzed in situ by gel-state $2 \mathrm{D}$ NMR, according to the method previously described, ${ }^{21,24}$ and the spectra were compared with those from the lignins (MWLs) isolated from the same samples. It is convenient to look at three characteristic regions of the HSQC spectra corresponding to nonoxygenated aliphatic, oxygenated aliphatic side chain, and aromatic ${ }^{13} \mathrm{C}-{ }^{1} \mathrm{H}$ correlations. The nonoxygenated aliphatic region, not plotted here, showed signals with little relevance to the structure of the cell wall polymers, except for a strong cross-signal at $\delta_{\mathrm{C}} / \delta_{\mathrm{H}} 20.6 / 2.00$, assigned to methyls in acetate groups attached to xylan moieties, as well as a weaker signal in the range $\delta_{\mathrm{C}} / \delta_{\mathrm{H}} 20.6 /$ $1.7-1.9$, corresponding to methyls in acetate groups attached to the lignin polymer. ${ }^{3}$

The oxygenated aliphatic side chain $\left(\delta_{\mathrm{C}} / \delta_{\mathrm{H}} 45-90 / 2.4-5.6\right)$ and the aromatic $\left(\delta_{\mathrm{C}} / \delta_{\mathrm{H}} 95-150 / 5.5-8.0\right)$ regions of the HSQC spectra of the whole cell walls from cortex and pith, and their isolated MWLs, are shown in Figures 3 and 4. It has 
Table 4. Identity and Relative Molar Abundances of the Compounds Released after Py/TMAH of Elephant Grass (P. purpureum) Cortex and Pith and Their Isolated Lignins (MWLs)

\begin{tabular}{|c|c|c|c|c|c|}
\hline & & cortex & MWL cortex & pith & MWL pith \\
\hline 1 & methoxybenzene & 1.7 & 0.6 & 2.2 & 0.6 \\
\hline 2 & 4-methoxytoluene & 2.7 & 1.8 & 2.3 & 0.9 \\
\hline 3 & 1,2-dimethoxybenzene & 2.9 & 0.8 & 4.2 & 0.4 \\
\hline 4 & 4-methoxystyrene & 16.2 & 10.4 & 13.8 & 5.7 \\
\hline 5 & 3,4-dimethoxytoluene & 0.7 & 1.9 & 1.9 & 0.7 \\
\hline 6 & 4-methoxybenzaldehyde & 3.3 & 1.3 & 3.1 & 1.8 \\
\hline 7 & trans-4-methoxypropenylbenzene & 1.4 & 1.5 & 2.2 & 0.9 \\
\hline 8 & 1,2,3-trimethoxybenzene & 1.7 & 1.2 & 2.6 & 0.6 \\
\hline 9 & 3,4-dimethoxystyrene & 4.5 & 2.0 & 3.7 & 1.1 \\
\hline 10 & 4-methoxybenzoic acid methyl ester & 0.9 & 0.4 & 0.3 & 0.5 \\
\hline 11 & 3,4,5-trimethoxytoluene & 0.8 & 2.0 & 0.8 & 1.1 \\
\hline 12 & 3,4-dimethoxybenzaldehyde & 1.7 & 1.9 & 1.5 & 1.8 \\
\hline 13 & 1-(3,4-dimethoxyphenyl)-1-propene & 0.8 & 1.2 & 1.5 & 0.5 \\
\hline 14 & 3,4,5-trimethoxystyrene & 1.0 & 1.4 & 1.0 & 1.0 \\
\hline 15 & 3,4-dimethoxyacetophenone & 1.0 & 0.4 & 0.4 & 0.4 \\
\hline 16 & 3,4-dimethoxybenzoic acid methyl ester & 0.8 & 1.1 & 1.4 & 1.1 \\
\hline 17 & cis-3-(4-methoxyphenyl)-3-propenoic acid methyl ester & 1.1 & 1.8 & 1.5 & 4.7 \\
\hline 18 & 3,4,5-trimethoxybenzaldehyde & 1.3 & 5.1 & 1.4 & 4.1 \\
\hline 19 & cis-1-(3,4-dimethoxyphenyl)-2-methoxyethylene & 0.2 & 0.5 & 0.4 & 0.5 \\
\hline 20 & trans-1-(3,4-dimethoxyphenyl)-2-methoxyethylene & 0.2 & 0.6 & 0.4 & 0.6 \\
\hline 21 & 1-(3,4,5-trimethoxyphenyl)-1-propene & 1.1 & 1.9 & 1.2 & 1.2 \\
\hline 22 & 3,4,5-trimethoxyacetophenone & 0.9 & 1.3 & 1.1 & 1.5 \\
\hline 23 & trans-3-(4-methoxyphenyl)-3-propenoic acid methyl ester & 45.6 & 53.8 & 43.1 & 63.7 \\
\hline 24 & 3,4,5-trimethoxybenzoic acid methyl ester & 1.0 & 1.4 & 1.1 & 1.8 \\
\hline 25 & cis-1-(3,4,5-trimethoxyphenyl)-2-methoxyethylene & 0.3 & 1.1 & 0.7 & 0.7 \\
\hline 26 & cis-3-(3,4-dimethoxyphenyl)-3-propenoic acid methyl ester & 0.5 & 0.1 & 0.4 & 0.1 \\
\hline 27 & trans-1-(3,4,5-trimethoxyphenyl)-2-methoxyethylene & 0.2 & 0.7 & 0.4 & 0.5 \\
\hline 28 & trans-1-(3,4-dimethoxyphenyl)-2,3-dimethoxyprop-1-ene & 0.6 & 1.0 & 0.3 & 0.5 \\
\hline \multirow[t]{2}{*}{29} & trans-3-(3,4-dimethoxyphenyl)-3-propenoic acid methyl ester & 5.0 & 0.8 & 5.1 & 1.1 \\
\hline & $p$-coumarate/ferulate ratio ${ }^{a}$ & 9.1 & 67.3 & 8.5 & 57.9 \\
\hline
\end{tabular}

already been shown that HSQC-NMR of DMSO- $d_{6}$ gels of ball-milled plant materials is an efficient method for the "in situ" analysis of the major structural features of native lignin in plants, without the need of prior isolation. ${ }^{21,24}$ Xylan polysaccharide signals $\left(\mathrm{X}_{2}, \mathrm{X}_{3}, \mathrm{X}_{4}, \mathrm{X}_{5}\right)$ were predominant in the hydroxylated aliphatic region of the spectra of the whole cell walls, which partially overlapped with some lignin signals, and also included signals from acetylated xylan moieties $\left(\mathrm{X}_{2}^{\prime}\right.$ and $\left.\mathrm{X}_{3}^{\prime}\right)$. On the other hand, the spectra of the MWLs presented mostly lignin signals that, in general terms, matched those observed in the HSQC spectra of their respective whole cell walls. The main lignin and carbohydrate cross-signals assigned in the HSQC spectra are listed in Table 5, and the main lignin substructures found are depicted in Figure 5.

The side-chain region of the spectra gave useful information about the different interunit linkages present in the lignin. In this region, cross-signals from methoxyls $\left(\delta_{\mathrm{C}} / \delta_{\mathrm{H}} 55.6 / 3.73\right)$ and side chains in $\beta-\mathrm{O}-4^{\prime}$ substructures $\mathbf{A}$ were the most prominent. The spectra of the whole cell walls and of their corresponding MWLs clearly showed the presence of intense signals in the range $\delta_{\mathrm{C}} / \delta_{\mathrm{H}} 62.7 / 3.83-4.19$ corresponding to the $\gamma$-C/H of $\gamma$-acylated units (including structure $\mathbf{A}^{\prime}$ ), together with the presence of signals from normally hydroxylated $\gamma$-carbons in $\beta-\mathrm{O}-4^{\prime}$ units $\mathrm{A}$ and other substructures (at $\delta_{\mathrm{C}} / \delta_{\mathrm{H}}$ $60.2 / 3.30$ and 3.70). The HSQC spectra therefore indicate that these lignins are extensively acylated at the $\gamma$-position of the lignin side chain. An estimation of the percentage of $\gamma$-acylation of the lignin side chain was performed by integration of the signals corresponding to the hydroxylated vs acylated $\gamma-\mathrm{C} / \mathrm{H}$ correlations in the HSQC spectra of the isolated MWLs, where the signals are better resolved and carbohydrates do not interfere, and ranged from $39 \%$ in the cortex to $55 \%$ in the pith lignin (Table 6). The spectra showed other prominent signals corresponding to $\beta-\mathrm{O}-4^{\prime}$ alkyl-aryl ether linkages $\mathrm{A}$. The $\mathrm{C}_{\alpha}-\mathrm{H}_{\alpha}$ correlations in $\beta-\mathrm{O}-4^{\prime}$ substructures were observed at $\delta_{\mathrm{C}} / \delta_{\mathrm{H}} 71.7 / 4.86$ (structures $\mathbf{A}$ and $\mathbf{A}^{\prime}$ ), while the $\mathrm{C}_{\beta}-\mathrm{H}_{\beta}$ correlations were observed at $\delta_{\mathrm{C}} / \delta_{\mathrm{H}} 85.8 / 4.11$ in normal $\gamma-\mathrm{OH} \beta-\mathrm{O}-4^{\prime}$ substructures $\mathrm{A}$ linked to a $\mathrm{S}$ unit but shifted to $\delta_{\mathrm{C}} / \delta_{\mathrm{H}} 83.0 / 4.32$ in $\gamma$-acylated $\beta-\mathrm{O}-4^{\prime}$ substructures $\mathbf{A}^{\prime}$, which overlaps with the $\mathrm{C}_{\beta}-\mathrm{H}_{\beta}$ correlations of normal $\gamma-\mathrm{OH} \beta-\mathrm{O}-4^{\prime}$ substructures $\mathrm{A}$ linked to a $\mathrm{G}$ unit at $\delta_{\mathrm{C}} / \delta_{\mathrm{H}} 83.5 / 4.28$. The $\mathrm{C}_{\beta}-\mathrm{H}_{\beta}$ correlations of $\gamma$-acylated $\beta-\mathrm{O}-4^{\prime}$ substructures $\mathbf{A}^{\prime}$ linked to a $\mathrm{G}$ unit shifted to $\delta_{\mathrm{C}} / \delta_{\mathrm{H}} 80.8 / 4.52$, and were clearly observed in the MWL from the pith, indicating an important acylation extent of G-lignin units in this lignin, as will be shown below. Other substructures were also observed in lower amounts. Phenylcoumaran $\left(\beta-5^{\prime}\right)$ substructures B were found, the signals for their $\mathrm{C}_{\alpha}-\mathrm{H}_{\alpha}$ and $\mathrm{C}_{\beta}-\mathrm{H}_{\beta}$ correlations being observed at $\delta_{\mathrm{C}} / \delta_{\mathrm{H}} 86.8 / 5.46$ and 53.5/3.46, and the $\mathrm{C}_{\gamma}-\mathrm{H}_{\gamma}$ correlation overlap with other $\mathrm{C}_{\gamma}-\mathrm{H}_{\gamma}$ signals around $\delta_{\mathrm{C}} / \delta_{\mathrm{H}} 62 / 3.8$. Small signals for resinol $\left(\beta-\beta^{\prime}\right)$ substructures $\mathrm{C}$ were also observed in the spectra, with their $\mathrm{C}_{\alpha}-\mathrm{H}_{\alpha}, \mathrm{C}_{\beta}-\mathrm{H}_{\beta}$ 
(a)
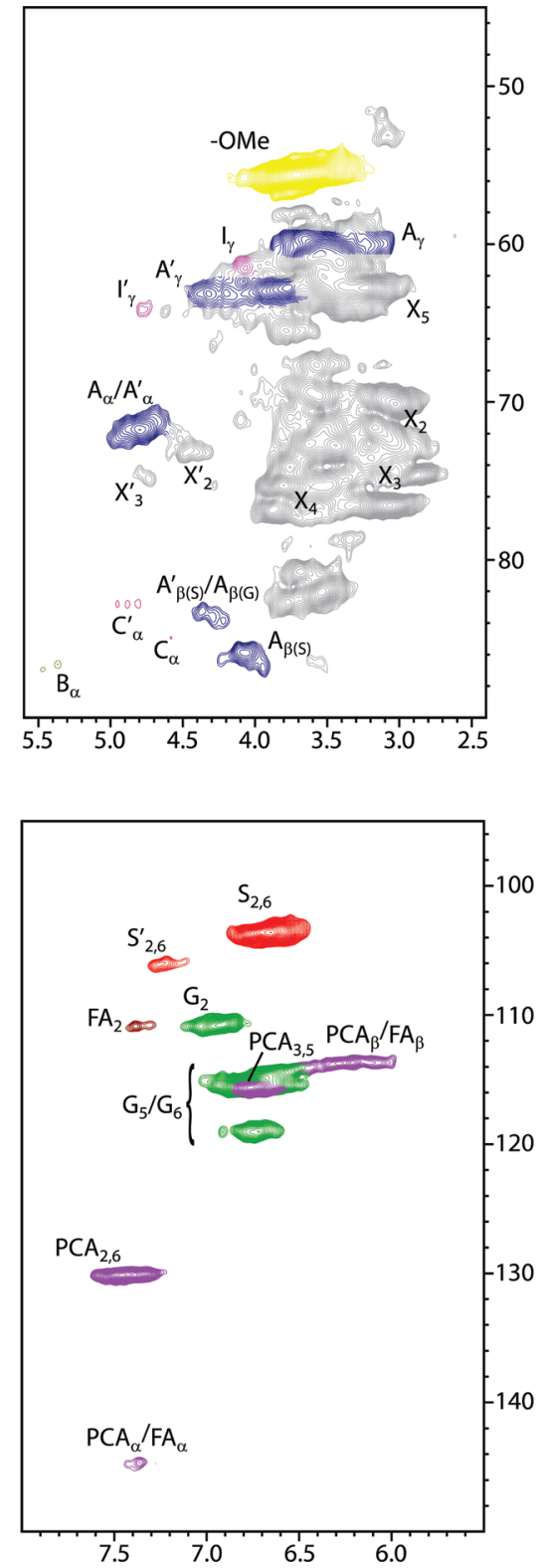

(b)
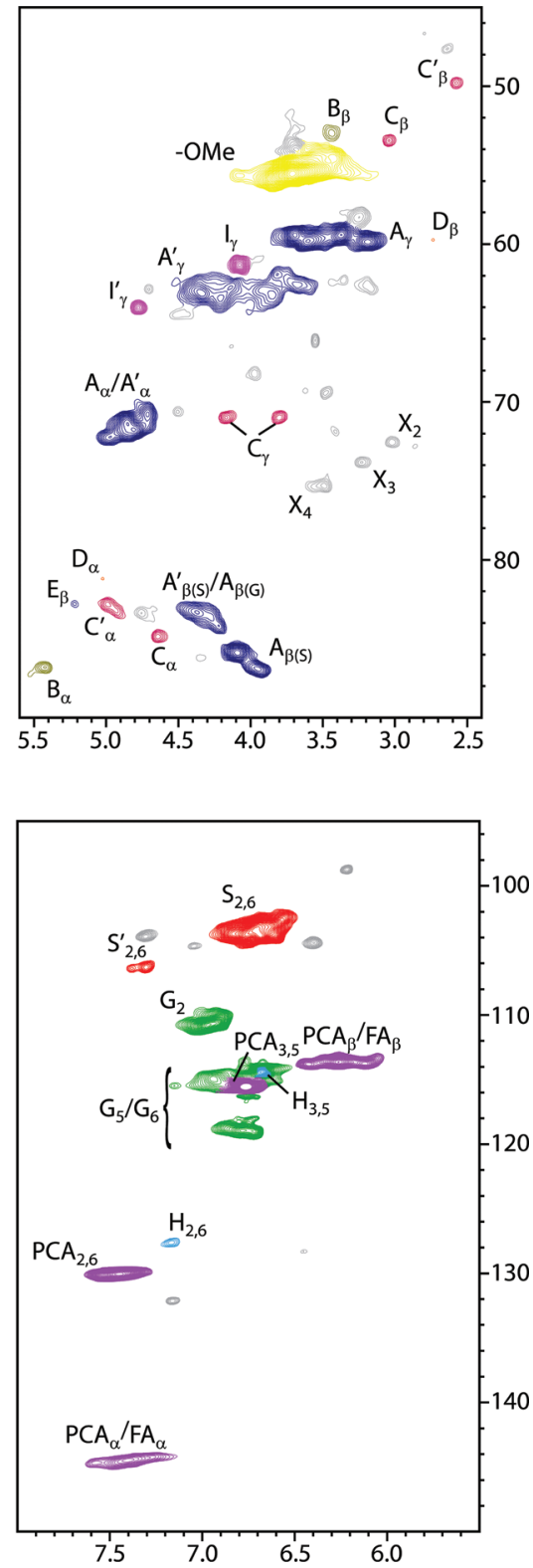

Figure 3. Side-chain $\left(\delta_{\mathrm{C}} / \delta_{\mathrm{H}} 45-90 / 2.40-5.60\right)$ and aromatic $\left(\delta_{\mathrm{C}} / \delta_{\mathrm{H}} 95-150 / 5.50-8.00\right)$ regions in the 2D HSQC NMR spectra of elephant grass (P. purpureum) cortex (a) and its isolated MWL (b). See Table 5 for signal assignments and Figure 5 for the main lignin structures identified.

and the double $\mathrm{C}_{\gamma}-\mathrm{H}_{\gamma}$ correlations at $\delta_{\mathrm{C}} / \delta_{\mathrm{H}} 84.8 / 4.67$, $53.5 / 3.06$ and $71.0 / 3.83$ and 4.19. Finally, small signals corresponding to spirodienone $\left(\beta-1^{\prime}\right)$ substructures (D) could also be observed in the spectrum (at contour levels lower than those plotted), their $\mathrm{C}_{\alpha}-\mathrm{H}_{\alpha}$ and $\mathrm{C}_{\beta}-\mathrm{H}_{\beta}$ correlations being at $\delta_{\mathrm{C}} / \delta_{\mathrm{H}} 81.2 / 5.09$ and 59.6/2.75. Other small signals in the sidechain region of the HSQC spectra corresponded to $\mathrm{C}_{\gamma}-\mathrm{H}_{\gamma}$ correlations (at $\delta_{\mathrm{C}} / \delta_{\mathrm{H}} 61.3 / 4.09$ and $64.0 / 4.79$ ) assigned to cinnamyl alcohol end-groups (I) and $\gamma$-acylated cinnamyl alcohol end-groups $\left(\mathrm{I}^{\prime}\right)$, and the $\mathrm{C}_{\beta}-\mathrm{H}_{\beta}$ correlations of $\alpha$-keto$\beta-\mathrm{O}-4$ ' substructures $(\mathrm{E})$.

Interestingly, signals for a $\beta-\beta^{\prime}$-linked tetrahydrofuran structure $\mathbf{C}^{\prime}$ were clearly seen in the spectra of both MWLs, with the characteristic $\mathrm{C}_{\alpha}-\mathrm{H}_{\alpha}$ and $\mathrm{C}_{\beta}-\mathrm{H}_{\beta}$ correlations at 82.8/ 5.00 and 49.8/2.59, as already described in kenaf, corn, and palms $^{54,55}$ and also reported in the lignins of sisal and abaca. ${ }^{22}$
These structures arise from the $\beta-\beta^{\prime}$ homocoupling of two $\gamma$-acylated sinapyl alcohol monomers and have been found in the lignins of several plants and with different acylating groups (acetates, $p$-coumarates and $p$-hydroxybenzoates). ${ }^{54,55}$ Therefore, the presence of this structure $\mathbf{C}^{\prime}$ is related to the high extent of $\gamma$-carbon acylation in the lignins of elephant grass, as shown above.

The main cross-signals in the aromatic regions of the HSQC spectra corresponded to the different lignin and $p$-hydroxycinnamate units. Signals from $p$-hydroxycinnamyl $(\mathbf{H})$, guaiacyl (G) and syringyl (S) units were observed in the spectra of the whole cell walls and in their isolated MWLs. The S-lignin units showed a prominent signal for the $\mathrm{C}_{2,6}-\mathrm{H}_{2,6}$ correlation at $\delta_{\mathrm{C}} / \delta_{\mathrm{H}} 103.8 / 6.69$, while the G-lignin units showed different correlations for $\mathrm{C}_{2}-\mathrm{H}_{2}\left(\delta_{\mathrm{C}} / \delta_{\mathrm{H}} 110.9 / 6.99\right)$, and for $\mathrm{C}_{5}-\mathrm{H}_{5}$ and $\mathrm{C}_{6}-\mathrm{H}_{6}\left(\delta_{\mathrm{C}} / \delta_{\mathrm{H}} 114.9 / 6.72\right.$ and 6.94, and 
(a)
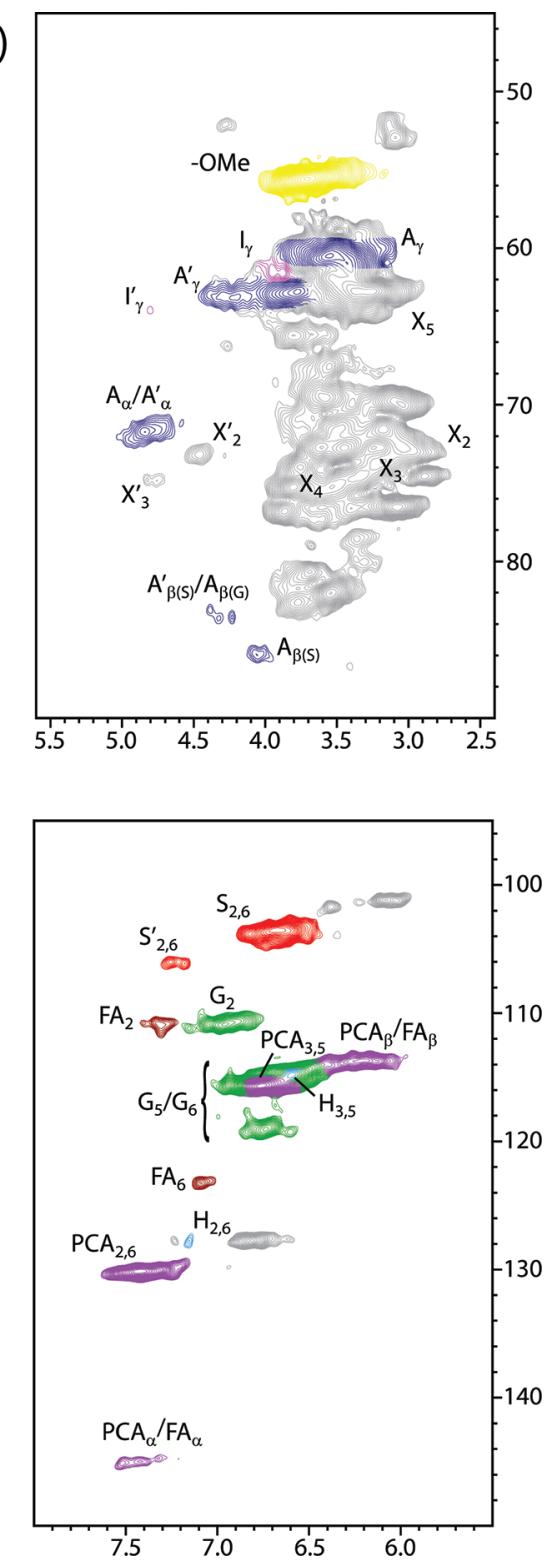

(b)
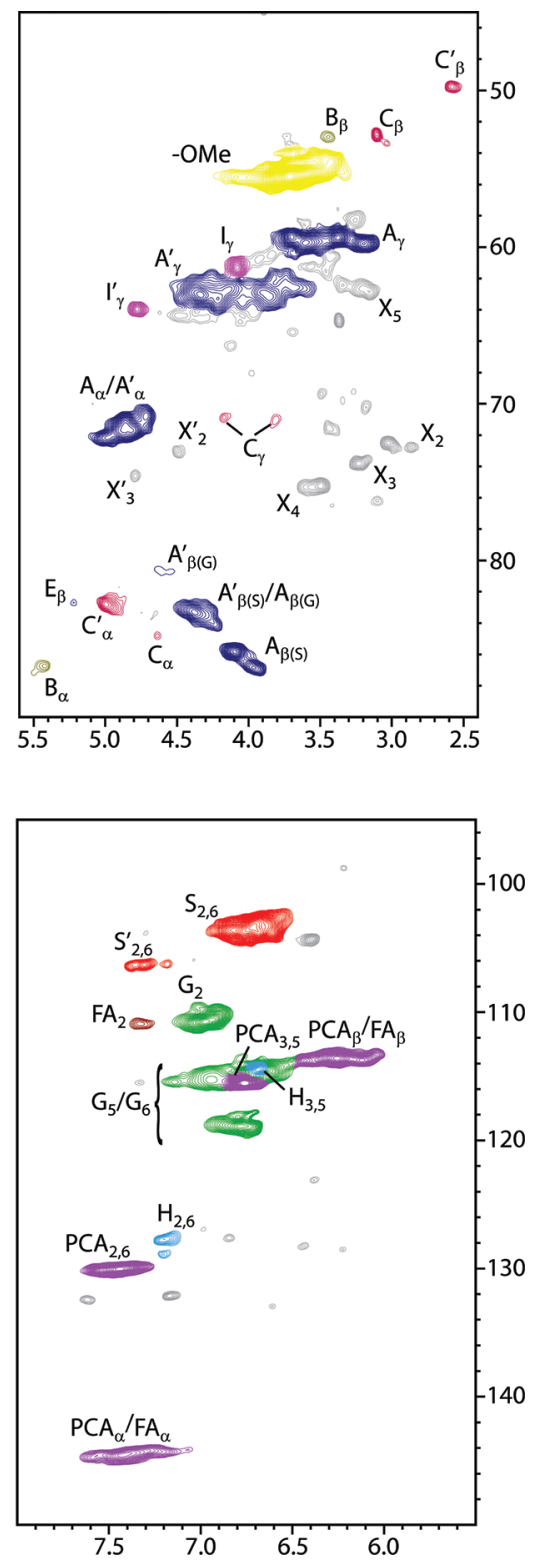

Figure 4. Side-chain $\left(\delta_{\mathrm{C}} / \delta_{\mathrm{H}} 45-90 / 2.40-5.60\right)$ and aromatic $\left(\delta_{\mathrm{C}} / \delta_{\mathrm{H}} 95-150 / 5.50-8.00\right)$ regions in the HSQC NMR spectra of elephant grass (P. purpureum) pith (a) and its isolated MWL (b). See Table 5 for signal assignments and Figure 5 for the main lignin structures identified.

118.7/6.77). Signals corresponding to $\mathrm{C}_{2,6}-\mathrm{H}_{2,6}$ correlations in $\mathrm{C}_{\alpha}$-oxidized S-lignin units $\left(\mathrm{S}^{\prime}\right)$ were observed at $\delta_{\mathrm{C}} / \delta_{\mathrm{H}} 106.1 /$ 7.32 and 106.4/7.19. Signals for $\mathrm{C}_{2,6}-\mathrm{H}_{2,6}$ of $\mathrm{H}$ lignin units at $\delta_{\mathrm{C}} / \delta_{\mathrm{H}} 128.0 / 7.23$ were also detected in the HSQC spectra, although in lower amounts. This confirms that the H-unit content in the lignins from these elephant grass samples, as in other grasses, is quite low $(\sim 3 \%$, Table 6$)$, and that the high abundance of "H units" observed upon pyrolysis was due to the presence of $p$-coumarate, as shown by Py-TMAH (although some overestimation of ester-forming structures is produced by this technique). It is a commonly accepted fallacy that grass lignins are high in $\mathrm{H}$ units: as discussed above, they are not! Prominent signals corresponding to $p$-coumarate structures (PCA) were observed in the spectra of the whole cell walls and of their isolated MWLs. Cross-signals corresponding to the $\mathrm{C}_{2,6}-\mathrm{H}_{2,6}$ at $\delta_{\mathrm{C}} / \delta_{\mathrm{H}} 130.0 / 7.46$ and $\mathrm{C}_{3,5}-\mathrm{H}_{3,5}$ at $\delta_{\mathrm{C}} / \delta_{\mathrm{H}} 115.5 / 6.77$ correlations of the aromatic ring and signals for the correlations of the unsaturated $\mathrm{C}_{\alpha}-\mathrm{H}_{\alpha}$ at $\delta_{\mathrm{C}} / \delta_{\mathrm{H}} 144.4 / 7.41$ and $\mathrm{C}_{\beta}-\mathrm{H}_{\beta}$ at $113.5 / 6.27$ of the $p$-coumarate unit were observed in this region of the HSQC spectra. Signals corresponding to the $\mathrm{C}_{2}-\mathrm{H}_{2}$ and $\mathrm{C}_{6}-\mathrm{H}_{6}$ correlations of ferulate moieties (FA) were also observed at $\delta_{\mathrm{C}} / \delta_{\mathrm{H}} 111.0 / 7.32$ and $123.3 / 7.10$ in the whole cell wall spectra. The correlations corresponding to the unsaturated $\mathrm{C}_{\alpha}-\mathrm{H}_{\alpha}$ and $\mathrm{C}_{\beta}-\mathrm{H}_{\beta}$ overlapped with those of the $p$-coumarate.

The molar composition of different lignin units $(H, G, S)$ and $p$-hydroxycinnamate ( $p$-coumarate, ferulate) in the cortex and in the pith, as well as in their isolated MWLs, as estimated from the HSQC data, is reflected in Table 6. The relative abundances of the main lignin interunit linkages were estimated only in the HSQC spectra of the MWLs because the high abundances of carbohydrate signals in the spectra of the whole cell walls interfere with quantitation of some lignin signals. The data indicated a similar lignin composition in the cortex and pith, with a low abundance of $\mathrm{H}$-lignin units and with similar $\mathrm{S} / \mathrm{G}$ ratio around 1.3 . On the other hand, $p$-coumarate is highly abundant in the whole cell walls of the cortex and pith, as well 
Table 5. Assignments of ${ }^{13} \mathrm{C}-{ }^{1} \mathrm{H}$ Correlation Signals in the 2D HSQC Spectra of the Whole Cell Walls of the Cortex and Pith of Elephant Grass (P. purpureum) and Their Isolated MWLs ${ }^{a}$

\begin{tabular}{|c|c|c|}
\hline label & $\delta_{\mathrm{C}} / \delta_{\mathrm{H}}(\mathrm{ppm})$ & assignment \\
\hline \multicolumn{3}{|c|}{ Lignin Cross-Peak Signals } \\
\hline $\mathrm{C}_{\beta}^{\prime}$ & $49.8 / 2.59$ & $\mathrm{C}_{\beta}-\mathrm{H}_{\beta}$ in $\gamma$-acylated $\beta-\beta^{\prime}$ tetrahydrofuran substructures $\left(\mathbf{C}^{\prime}\right)$ \\
\hline $\mathrm{B}_{\beta}$ & $53.5 / 3.46$ & $\mathrm{C}_{\beta}-\mathrm{H}_{\beta}$ in $\beta-5^{\prime}$ phenylcoumaran substructures (B) \\
\hline $\mathrm{C}_{\beta}$ & $53.5 / 3.06$ & $\mathrm{C}_{\beta}-\mathrm{H}_{\beta}$ in $\beta-\beta^{\prime}$ resinol substructures $(\mathbf{C})$ \\
\hline$-\mathrm{OCH}_{3}$ & $55.6 / 3.73$ & $\mathrm{C}-\mathrm{H}$ in methoxyls \\
\hline $\mathrm{A}_{\gamma}$ & $59.4 / 3.40$ and 3.72 & $\mathrm{C}_{\gamma}-\mathrm{H}_{\gamma}$ in $\gamma$-hydroxylated $\beta-\mathrm{O}-4^{\prime}$ substructures (A) \\
\hline $\mathrm{D}_{\beta}$ & $59.6 / 2.75$ & $\mathrm{C}_{\beta}-\mathrm{H}_{\beta}$ in spirodienone substructures (D) \\
\hline $\mathrm{I}_{\gamma}$ & $61.3 / 4.09$ & $\mathrm{C}_{\gamma}-\mathrm{H}_{\gamma}$ in cinnamyl alcohol end-groups (I) \\
\hline $\mathrm{A}_{\gamma}^{\prime}$ & $62.7 / 3.83-4.30$ & $\mathrm{C}_{\gamma}-\mathrm{H}_{\gamma}$ in $\gamma$-acylated $\beta-\mathrm{O}-4^{\prime}$ substructures $\left(\mathbf{A}^{\prime}\right)$ \\
\hline $\mathrm{I}_{\gamma}^{\prime}$ & $64.0 / 4.79$ & $\mathrm{C}_{\gamma}-\mathrm{H}_{\gamma}$ in $\gamma$-acylated cinnamyl alcohol end-groups $\left(\mathbf{I}^{\prime}\right)$ \\
\hline $\mathrm{C}_{\gamma}$ & $71.0 / 3.83$ and 4.19 & $\mathrm{C}_{\gamma}-\mathrm{H}_{\gamma}$ in $\beta-\beta^{\prime}$ resinol substructures $(\mathbf{C})$ \\
\hline $\mathrm{A}_{\alpha} / \mathrm{A}_{\alpha}^{\prime}$ & $71.7 / 4.86$ & $\mathrm{C}_{\alpha}-\mathrm{H}_{\alpha}$ in $\beta-\mathrm{O}-4^{\prime}$ substructures $\left(\mathbf{A}, \mathbf{A}^{\prime}\right)$ \\
\hline $\mathrm{A}_{\beta(\mathrm{G})}^{\prime}$ & $80.8 / 4.58$ & $\mathrm{C}_{\beta}-\mathrm{H}_{\beta}$ in $\gamma$-acylated $\beta-\mathrm{O}-4^{\prime}$ substructures linked to a $\mathrm{G}$ unit $\left(\mathbf{A}^{\prime}\right)$ \\
\hline $\mathrm{D}_{\alpha}$ & $81.2 / 5.09$ & $\mathrm{C}_{\alpha}-\mathrm{H}_{\alpha}$ in spirodienone substructures (D) \\
\hline $\mathrm{C}_{\alpha}^{\prime}$ & $82.8 / 5.00$ & $\mathrm{C}_{\alpha}-\mathrm{H}_{\alpha}$ in $\gamma$-acylated $\beta-\beta^{\prime}$ tetrahydrofuran structures $\left(\mathbf{C}^{\prime}\right)$ \\
\hline $\mathrm{E}_{\beta}$ & $82.8 / 5.23$ & $\mathrm{C}_{\beta}-\mathrm{H}_{\beta}$ in $\alpha$-oxidized $\beta-\mathrm{O}-4^{\prime}$ substructures $(\mathbf{E})$ \\
\hline $\mathrm{A}_{\beta(\mathrm{G})} / \mathrm{A}_{\beta(\mathrm{S})}^{\prime}$ & $83.5 / 4.28$ and $83.0 / 4.32$ & $\begin{array}{l}\mathrm{C}_{\beta}-\mathrm{H}_{\beta} \text { in } \beta-\mathrm{O}-4^{\prime} \text { substructures linked to a } \mathrm{G} \text { unit }(\mathbf{A}) \text { and in } \gamma \text {-acylated } \\
\beta-\mathrm{O}-4^{\prime} \text { substructures linked to a } \mathrm{S} \text { unit }\left(\mathbf{A}^{\prime}\right)\end{array}$ \\
\hline $\mathrm{C}_{\alpha}$ & $84.8 / 4.67$ & $\mathrm{C}_{\alpha}-\mathrm{H}_{\alpha}$ in $\beta-\beta^{\prime}$ resinol substructures $(\mathbf{C})$ \\
\hline $\mathrm{A}_{\beta(\mathrm{S})}$ & $85.8 / 4.11$ & $\mathrm{C}_{\beta}-\mathrm{H}_{\beta}$ in $\beta-\mathrm{O}-4^{\prime}$ substructures linked to a $\mathrm{S}$ unit (A) \\
\hline $\mathrm{B}_{\alpha}$ & $86.8 / 5.46$ & $\mathrm{C}_{\alpha}-\mathrm{H}_{\alpha}$ in phenylcoumaran substructures $(\mathbf{B})$ \\
\hline$S_{2,6}$ & $103.8 / 6.69$ & $\mathrm{C}_{2}-\mathrm{H}_{2}$ and $\mathrm{C}_{6}-\mathrm{H}_{6}$ in etherified syringyl units $(\mathbf{S})$ \\
\hline$S_{2,6}^{\prime}$ & $106.1 / 7.32$ and $106.4 / 7.19$ & $\mathrm{C}_{2}-\mathrm{H}_{2}$ and $\mathrm{C}_{6}-\mathrm{H}_{6}$ in $\alpha$-oxidized syringyl units $\left(\mathbf{S}^{\prime}\right)$ \\
\hline $\mathrm{G}_{2}$ & $110.9 / 6.99$ & $\mathrm{C}_{2}-\mathrm{H}_{2}$ in guaiacyl units $(\mathbf{G})$ \\
\hline $\mathrm{FA}_{2}$ & $111.0 / 7.32$ & $\mathrm{C}_{2}-\mathrm{H}_{2}$ in ferulic acid units (FA) \\
\hline $\mathrm{PCA}_{\beta}$ and $\mathrm{FA}_{\beta}$ & $113.5 / 6.27$ & $\mathrm{C}_{\beta}-\mathrm{H}_{\beta}$ in $p$-coumarate (PCA) and ferulate (FA) \\
\hline $\mathrm{G}_{5} / \mathrm{G}_{6}$ & $\begin{array}{l}114.9 / 6.72 \text { and } 6.94, \\
118.7 / 6.77\end{array}$ & $\mathrm{C}_{5}-\mathrm{H}_{5}$ and $\mathrm{C}_{6}-\mathrm{H}_{6}$ in guaiacyl units $(\mathbf{G})$ \\
\hline $\mathrm{PCA}_{3,5}$ & $115.5 / 6.77$ & $\mathrm{C}_{3}-\mathrm{H}_{3}$ and $\mathrm{C}_{5}-\mathrm{H}_{5}$ in $p$-coumarate (PCA) \\
\hline $\mathrm{FA}_{6}$ & $123.3 / 7.10$ & $\mathrm{C}_{6}-\mathrm{H}_{6}$ in ferulate (FA) \\
\hline $\mathrm{H}_{2,6}$ & $128.0 / 7.23$ & $\mathrm{C}_{2,6}-\mathrm{H}_{2,6}$ in $p$-hydroxyphenyl units $(\mathbf{H})$ \\
\hline $\mathrm{PCA}_{2,6}$ & $130.0 / 7.46$ & $\mathrm{C}_{2}-\mathrm{H}_{2}$ and $\mathrm{C}_{6}-\mathrm{H}_{6}$ in $p$-coumarate (PCA) \\
\hline $\mathrm{PCA}_{\alpha}$ and $\mathrm{FA}_{\alpha}$ & $144.4 / 7.41$ & $\mathrm{C}_{\alpha}-\mathrm{H}_{\alpha}$ in $p$-coumarate (PCA) and ferulate (FA) \\
\hline \multicolumn{3}{|c|}{ Polysaccharide Cross-Peak Signals } \\
\hline $\mathrm{X}_{5}$ & $63.2 / 3.26$ and 3.95 & $\mathrm{C}_{5}-\mathrm{H}_{5}$ in $\beta$-D-xylopyranoside \\
\hline $\mathrm{X}_{2}$ & $72.9 / 3.14$ & $\mathrm{C}_{2}-\mathrm{H}_{2}$ in $\beta$-D-xylopyranoside \\
\hline $\mathrm{X}_{2}^{\prime}$ & $73.5 / 4.61$ & $\mathrm{C}_{2}-\mathrm{H}_{2}$ in 2 - $O$-acetyl- $\beta$-D-xylopyranoside \\
\hline $\mathrm{X}_{3}$ & $74.1 / 3.32$ & $\mathrm{C}_{3}-\mathrm{H}_{3}$ in $\beta$-D-xylopyranoside \\
\hline $\mathrm{X}_{3}^{\prime}$ & $74.9 / 4.91$ & $\mathrm{C}_{3}-\mathrm{H}_{3}$ in 3 - $O$-acetyl- $\beta$-D-xylopyranoside \\
\hline $\mathrm{X}_{4}$ & $75.6 / 3.63$ & $\mathrm{C}_{4}-\mathrm{H}_{4}$ in $\beta$-D-xylopyranoside \\
\hline
\end{tabular}

as in their isolated MWLs, while the abundance of ferulate is much lower in the isolated MWL than in the respective whole cell walls, as previously observed by $\mathrm{Py}-\mathrm{GC} / \mathrm{MS}$. This fact indicates that ferulate is mostly or entirely attached to the carbohydrates (primarily, as has been established in other grasses, ${ }^{56}$ acylating the $\mathrm{C}_{5}-\mathrm{OH}$ of arabinosyl moieties in (glucurono)arabinoxylans)), while $p$-coumarate is predominantly attached to the lignin moiety. This information, together with the high extent of acylation of the $\gamma$-OH observed in these lignins, seems to indicate that $p$-coumarate is mostly acylating the $\gamma$-position of the lignin side chain, as also observed in other lignins, ${ }^{26,33,41,43,47,48,51,52}$ although no direct evidence of the nature of the group acylating the $\gamma$-carbon can be provided by HSQC. Esterification of $p$-coumarate to the $\alpha$-carbon can be excluded from the absence of the corresponding cross-signal in the HSQC spectra, which is at $\sim 6.1 / 75 \mathrm{ppm}^{51,57}$
In both MWLs, the main lignin substructure present is the $\beta-\mathrm{O}-4$ ' alkyl aryl ether, which accounts for up to $82 \%$ of all interunit linkages in the cortex and in the pith, while condensed linkages $\left(\beta-\beta^{\prime}\right.$ resinols, $\beta-5^{\prime}$ phenylcoumarans, $\beta-1^{\prime}$ spirodienones) are present in minor amounts. In particular, there is a strikingly low proportion of resinol $\left(\beta-\beta^{\prime}\right)$ structures, which account for only $2 \%$ of interunit linkages in the cortex and only $1 \%$ in the pith lignin. This low proportion of resinol structures is related to the high extent of $\gamma$-acylation of the lignin side chain, as also observed in other highly acylated lignins. ${ }^{22,26}$ If the $\gamma-\mathrm{OH}$ of a monolignol is acylated, the formation of the normal resinol structures cannot occur because a free $\gamma$ hydroxyl is needed to rearomatize the intermediate quinone methide (following the radical dehydrodimerization step). Instead, new tetrahydrofuran structures are formed from either $\beta-\beta^{\prime}$ homocoupling of two acylated monolignols or crosscoupling of a monolignol with an acylated monolignol. $22,26,54,55,58$ 
<smiles>CCOc1c(C)cc([C@@H](O)[C@H](OCC)c2c(C)cc(I)cc2OC)cc1OC</smiles>

A

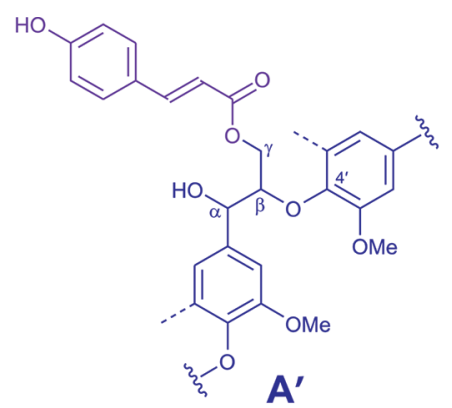<smiles>COc1cc(C)cc2c1OC(c1cc(C)cc(OC)c1OC)C2CO</smiles>

B<smiles>CCOc1c(C)cc([C@@H]2O[C@@H]3C(c4cc(OC)c(OC)c(OC)c4)OC[C@H]32)cc1OC</smiles><smiles>[R9]CC1C(CO)C(c2cc(C)c(OCC)c(OC)c2)O[C@H]1c1cc(C)c(OCC)c(OC)c1</smiles>

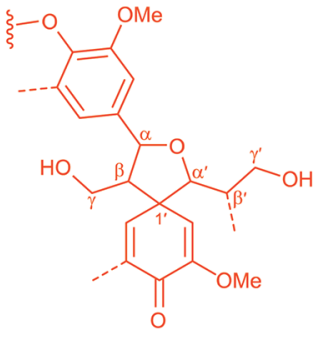

D<smiles>COc1cc(I)cc(C)c1OC(CO)C(=O)c1cc(OC)c(OC)c(OC)c1</smiles><smiles>CCOc1c(C)cc(/C=C/CO)cc1OC</smiles><smiles>CCOC(=O)C=Cc1ccc(O)cc1</smiles>

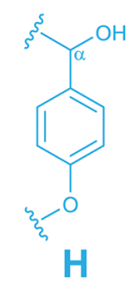<smiles>CCOc1cc(C(C)O)ccc1OC</smiles><smiles>COc1cc(C(C)O)cc(OC)c1OCS</smiles><smiles>[R]C(=O)c1cc(OC)c(OCS)c(OC)c1</smiles>

Figure 5. Main structures present in the lignins of elephant grass (P. purpureum): (A) $\beta-\mathrm{O}-4$ ' structures; $\left(\mathbf{A}^{\prime}\right) \beta-\mathrm{O}-4^{\prime}$ structures with acylated (by acetates or $p$-coumarates) $\gamma$-OH; (B) phenylcoumaran structures formed by $\beta-5^{\prime}$ coupling; (C) resinol structures formed by $\beta-\beta^{\prime}$ coupling; $\left(\mathbf{C}^{\prime}\right)$ tetrahydrofuran structures formed by $\beta-\beta$ coupling of monolignols acylated at the $\gamma$-carbon; (D) spirodienone structures formed by $\beta-1^{\prime}$ coupling; (E) $\mathrm{C}_{\alpha}$-oxidized $\beta$-O-4' structures; (I) $p$-hydroxycinnamyl alcohol end-groups; (I') $p$-hydroxycinnamyl alcohol end-groups acylated at the $\gamma$-OH; (PCA) $p$-coumarate units; (FA) ferulate units; $(\mathbf{H})$ p-hydroxyphenyl units; $(\mathbf{G})$ guaiacyl units; $(\mathbf{S})$ syringyl units; $\left(\mathbf{S}^{\prime}\right)$ oxidized syringyl units bearing a carbonyl (R, lignin side-chain) or carboxyl ( $\mathrm{R}$, hydroxyl group) group at $\mathrm{C} \alpha$.

Interestingly, tetrahydrofuran structures $\mathbf{C}^{\prime}$ formed by $\beta-\beta^{\prime}$ homocoupling of two $\gamma$-acylated monolignols are also present in these lignins, being especially abundant in the pith (5\% of all interunit linkages), and corresponding with its higher degree of $\gamma$-acylation (55\% of all side chains). The total amount of $\beta-\beta^{\prime}$ structures (including resinols and tetrahydrofurans) is similar (5-6\% of all interunit linkages) in both lignins from cortex and pith, and this value is similar to that noted in other lignins without monolignol acylation, but with similar S/G levels. ${ }^{20}$

DFRC (and DFRC'). The HSQC data shown above indicate that the lignins in the cortex and pith of elephant grass are heavily acylated at the $\gamma$-position of the side chain, but cannot provide additional information on the nature of the acylating group. The DFRC degradation method, which cleaves $\alpha$ - and $\beta$-ether linkages in the lignin polymer leaving $\gamma$-esters intact, $^{30-33}$ seems to be the most appropriate method for the analysis of $\gamma$-acylated lignins.

The chromatograms of the DFRC degradation products of the MWLs isolated from the cortex and pith of elephant grass are shown in Figure 6. The lignins released the cis- and trans-isomers of $p$-hydroxyphenyl $(t \mathrm{H})$, guaiacyl ( $c \mathrm{G}$ and $t \mathrm{G})$, and syringyl ( $c S$ and $t S$ ) lignin monomers (as their acetylated derivatives) arising from normal $(\gamma-\mathrm{OH})$ units in lignin. The presence of important peaks corresponding to $\gamma$-p-coumaroylated syringyl 
Table 6. Structural Characteristics (Lignin Interunit Linkages, End-Groups, Percentage of $\gamma$-Acylation, Relative Molar Composition of the Lignin Aromatic Units, S/G Ratio and p-Coumarate/and Ferulate Content and Ratio) from Integration of ${ }^{13} \mathrm{C}-{ }^{1} \mathrm{H}$ Correlation Signals in the HSQC Spectra of Whole Cell Walls of Cortex and Pith of Elephant Grass (P. purpureum) and Their Isolated MWLs

\begin{tabular}{|c|c|c|c|c|}
\hline & cortex & MWL cortex & pith & MWL pith \\
\hline \multicolumn{5}{|l|}{ lignin interunit linkages (\%) } \\
\hline$\beta-\mathrm{O}-4^{\prime}$ substructures $\left(\mathbf{A} / \mathbf{A}^{\prime}\right)$ & & 82 & & 82 \\
\hline$\beta-5^{\prime}$ phenylcoumaran substructures (B) & & 8 & & 7 \\
\hline$\beta-\beta^{\prime}$ resinol substructures $(\mathbf{C})$ & & 2 & & 1 \\
\hline$\beta-\beta^{\prime}$ tetrahydrofuran substructures $\left(\mathbf{C}^{\prime}\right)$ & & 3 & & 5 \\
\hline$\beta-1^{\prime}$ spirodienone substructures & & 2 & & 2 \\
\hline$\alpha$-oxidized $\beta-\mathrm{O}-4^{\prime}$ substructures (E) & & 2 & & 3 \\
\hline \multicolumn{5}{|l|}{ lignin end-groups ${ }^{a}$} \\
\hline cinnamyl alcohol end-groups (I) & & 6 & & 7 \\
\hline$\gamma$-acylated cinnamyl alcohol end-groups $\left(\mathbf{I}^{\prime}\right)$ & & 3 & & 4 \\
\hline lignin side-chain $\gamma$-acylation (\%) & & 39 & & 55 \\
\hline \multicolumn{5}{|l|}{ lignin aromatic units $b$} \\
\hline $\mathrm{H}(\%)$ & 0 & 3 & 3 & 3 \\
\hline $\mathrm{G}(\%)$ & 44 & 40 & 42 & 39 \\
\hline $\mathrm{S}(\%)$ & 56 & 57 & 55 & 58 \\
\hline S/G ratio & 1.3 & 1.4 & 1.3 & 1.5 \\
\hline \multicolumn{5}{|l|}{$p$-hydroxycinnamates ${ }^{c}$} \\
\hline$p$-coumarates $(\%)$ & 26 & 29 & 39 & 40 \\
\hline ferulates (\%) & 11 & 3 & 16 & 4 \\
\hline$p$-coumarates/ferulates ratio & 2.4 & 9.7 & 2.4 & 10.0 \\
\hline
\end{tabular}

${ }^{a}$ Expressed as a fraction of the total lignin inter-unit linkage types A-E. ${ }^{b}$ Molar percentages $(\mathrm{H}+\mathrm{G}+\mathrm{S}=100) .{ }^{c}$-Coumarate and ferulate levels expressed as a fraction of lignin content $(H+G+S)$. Because $p$-coumarate and ferulate groups are terminal, freely rotating, and therefore have longer relaxation times than internal lignin units, they overquantitate (relative to the lignin) by HSQC integration.

$\left(c S_{p c}\right.$ and $\left.t S_{p c}\right)$ and guaiacyl $\left(c \mathrm{G}_{p c}\right.$ and $\left.t \mathrm{G}_{p c}\right)$ lignin units in the DFRC chromatograms confirmed that $p$-coumarate groups are attached to the $\gamma$-carbon of these lignins, and predominantly on syringyl units; minor amounts of the guaiacyl $p$-coumarate $\left(c \mathrm{G}_{p c}\right.$ and $\left.t \mathrm{G}_{p c}\right)$ DFRC monomer conjugates could also be detected in both MWLs.

As noted above, signals for acetate groups $\gamma$-attached to lignin moiety were also observed in the HSQC spectra, including in the MWLs and indicating that acetates might also acylate the $\gamma-\mathrm{OH}$ of these lignins, as widely occurs in many other lignins. $^{12,26,27,34,35,59}$ The original DFRC degradation method, however, does not allow the analysis of natively acetylated lignin because the degradation products are acetylated during the analytical procedure, but with appropriate modification of the protocol by substituting acetylating reagents with propionylating reagents (in the so-called DFRC' method) it is also possible to obtain information about the occurrence of native lignin acetylation. ${ }^{26,34,35}$ Figure 7 shows the chromatograms of the DFRC' degradation products released from the MWLs isolated from the cortex and pith of elephant grass. The lignins released the cis- and trans-isomers of guaiacyl ( $c \mathrm{G}$ and $t \mathrm{G}$ ) and syringyl ( $c S$ and $t S$ ) lignin monomers (as their propionylated derivatives) arising from normal $(\gamma-\mathrm{OH})$ units in lignin. In addition, the presence of $\gamma$-acetylated guaiacyl $\left(c \mathrm{G}_{\mathrm{ac}}\right.$ and $\left.t \mathrm{G}_{\mathrm{ac}}\right)$ and syringyl $\left(\mathrm{cS}_{\mathrm{ac}}\right.$ and $\left.t \mathrm{~S}_{\mathrm{ac}}\right)$ lignin units could also be observed in the chromatograms, indicating that native acetylation at the $\gamma-\mathrm{OH}$ of the lignin side chain also occurred in these lignins, although to a low extent. Low levels of lignin acetylation, with a preference for $\mathrm{G}$ units, were also found in other grasses, such as bamboo. ${ }^{35}$

The results from the DFRC and DFRC' analysis of the MWLs isolated from the cortex and pith of elephant grass, namely, the molar yields of the released monomers $\left(H, G, G_{a c}\right.$
$\left.\mathrm{G}_{p \mathrm{c}}, \mathrm{S}, \mathrm{S}_{\mathrm{ac}}, \mathrm{S}_{p c}\right)$, as well as the percentages of naturally acetylated guaiacyl $\left(\% \mathrm{G}_{\mathrm{ac}}\right)$ and syringyl $\left(\% \mathrm{~S}_{\mathrm{ac}}\right)$ and $p$-coumaroylated guaiacyl $\left(\% \mathrm{G}_{p c}\right)$ and syringyl $\left(\% \mathrm{~S}_{p c}\right)$ lignin units, are presented in Table 7. The data indicate that a high extent of $\gamma$-acylation occurs in the lignins of both the cortex and pith of the elephant grass, and that $p$-coumarate is the main group acylating these lignins, with lower amounts of acetates, in agreement with the NMR data. While $p$-coumarate groups are preferentially attached to syringyl units in both fractions, acetates are attached preferentially to $S$ units in the cortex and to $G$ units in the pith lignin. We find this intriguing as the high levels of $\gamma$ acetylation in various dicots such as kenaf or jute are heavy on syringyl units. ${ }^{35,58,59}$

The monolignol conjugates sinapyl acetate and sinapyl $p$ coumarate have been demonstrated to behave as monomers in lignification, participating normally in coupling and crosscoupling reactions. ${ }^{26,35,54,55,58,60}$ If the $\gamma$-OH of a monolignol is acylated, however, the formation of the normal resinol structures cannot occur because a free $\gamma$-hydroxyl is needed to rearomatize the quinone methide moiety. Instead, new tetrahydrofuran structures are formed from the $\beta-\beta^{\prime}$ homocoupling and cross-coupling reactions involving acylated monolignols. ${ }^{22,26,35,54,55,58}$ Since $p$-coumarates are by far the main group acylating the sinapyl alcohol monomer, as seen above, it is clear that the tetrahydrofuran structure $\mathbf{C}^{\prime}$, identified in the HSQC spectra, is formed from the $\beta-\beta^{\prime}$ coupling of two sinapyl $p$-coumarate monomers, and will bear two $p$-coumarate groups in its structure, as in Figure 8 . When $p$-coumaroylated sinapyl alcohol dimerizes, it forms the $\beta$ - $\beta$-coupled bisquinone methide intermediate. However, this intermediate cannot be rearomatized by internal trapping; rearomatization will occur after water attack on one quinone methide moiety with the resulting $\alpha-\mathrm{OH}$ attacking the other quinone methide 

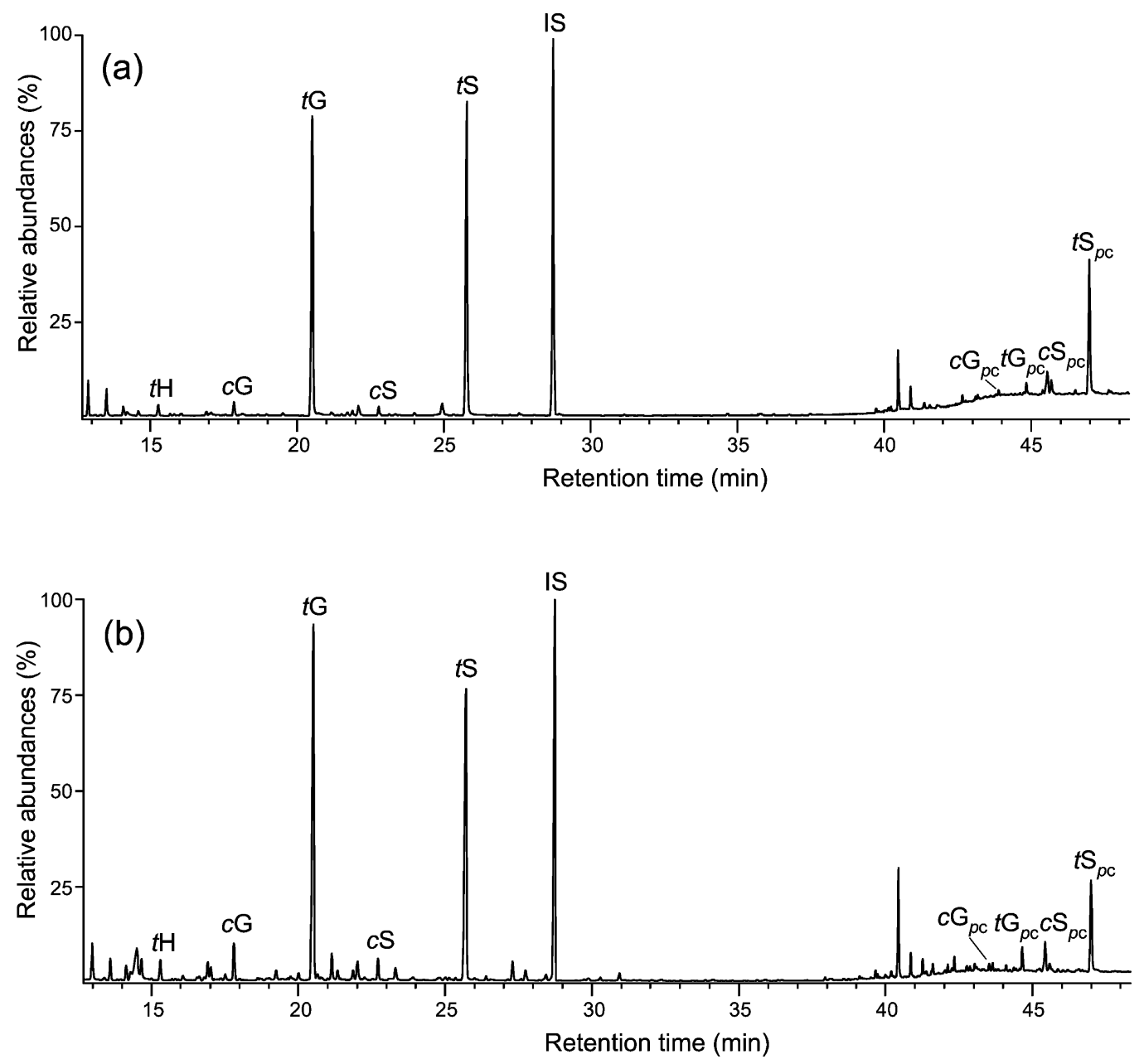

Figure 6. GC-TIC (TIC: total ion current) chromatograms of the DFRC degradation products from the MWLs isolated from elephant grass ( $P$. purpureum) cortex (a) and pith (b), showing the presence of syringyl (and minor guaiacyl) units acylated by $p$-coumarate moieties. $c \mathrm{G}, t \mathrm{G}, c \mathrm{~S}$ and $t S$ are the normal cis- and trans-coniferyl and sinapyl alcohol (guaiacyl and syringyl) monomers (as their acetate derivatives). $c \mathrm{G}_{p \mathcal{c}} t \mathrm{G}_{p \mathcal{c}} c \mathrm{~S}_{p c}$ and $t \mathrm{~S}_{p c}$ are the cis- and trans-coniferyl and sinapyl $p$-coumarates (as their acetate derivatives). IS: internal standard (4,4'-ethylenebisphenol). Nonlabeled peaks eluting at $40-42 \mathrm{~min}$ are from carbohydrate impurities.

Table 7. Abundance ( $\mu \mathrm{mol} / \mathrm{g}$ of Lignin) of the Monomers Obtained from DFRC and DFRC' Degradation of the MWLs Isolated from the Cortex and Pith of Elephant Grass (P. purpureum) and Relative Percentages of the Different Acylated (Acetylated and p-Coumaroylated) Lignin Monomers

\begin{tabular}{|c|c|c|c|c|c|c|c|c|c|c|c|}
\hline & $\mathrm{H}$ & G & $\mathrm{G}_{\mathrm{ac}}$ & $\mathrm{G}_{p c}$ & $S$ & $\mathrm{~S}_{\mathrm{ac}}$ & $S_{p c}$ & $\% \mathrm{G}_{\mathrm{ac}}{ }^{a}$ & $\% \mathrm{G}_{p c}{ }^{b}$ & $\% \mathrm{~S}_{\mathrm{ac}}{ }^{c}$ & $\% \mathrm{~S}_{p c}{ }^{d}$ \\
\hline MWL cortex & 4.6 & 156.6 & 4.1 & 3.4 & 191.2 & 17.7 & 86.7 & 2.5 & 2.0 & 6.0 & 29.3 \\
\hline MWL pith & 2.8 & 74.9 & 8.0 & 3.5 & 79.2 & 2.1 & 26.0 & 9.3 & 4.1 & 2.0 & 24.2 \\
\hline
\end{tabular}

$a_{\%} G_{a c}$ is the percentage of acetylated $G$ units $\left(G_{a c}\right)$ with respect to the total $G$ units $\left(G, G_{a c}, G_{p c}\right) .{ }^{b} \% G_{p c}$ is the percentage of $p$-coumaroylated $G$ units $\left(G_{p c}\right)$ with respect to the total $G$ units $\left(G, G_{a c}, G_{p c}\right) . c_{\%} S_{a c}$ is the percentage of acetylated $S$ units $\left(S_{a c}\right)$ with respect to the total $S$ units $\left(S, S_{a c}, S_{p c}\right)$. $d_{\%} S_{p c}$ is the percentage of $p$-coumaroylated $S$ units $\left(S_{p c}\right)$ with respect to the total $S$ units $\left(S, S_{a c}, S_{p c}\right)$.

to form the tetrahydrofuran structure $\mathrm{C}^{\prime}$. The $p$-coumaroyl monolignol transferase involved in the $p$-coumaroylation of sinapyl alcohol has already been described in grasses, ${ }^{47}$ and a candidate gene has now been identified. ${ }^{61}$ The presence of these tetrahydrofuran substructures in the lignin polymer here is indicative of the occurrence of pre-p-coumaroylated monolignols that participate in coupling and cross-coupling reactions in the lignification of elephant grass, and therefore implicate the presence of analogous transferases in this plant.

In conclusion, the analyses of the lignins from the cortex and pith of elephant grass indicate that they have a typical G-S lignin, with low amounts $(\sim 3 \%)$ of $\mathrm{H}$ units, and a $\mathrm{S} / \mathrm{G}$ ratio of $1.3-1.5$, depending on the analytical method used. The analyses also indicate the presence of high amounts of $p$-coumarate groups on lignin which acylate the $\gamma-\mathrm{OH}$ of the lignin side chains, and preferentially on syringyl units. Minor amounts of acetate groups were also found acylating the lignin. The main interunit linkage present in these lignins is the $\beta-\mathrm{O}-4^{\prime}$ alkyl aryl ether ( $82 \%$ of all interunit linkages), with lower amounts of condensed linkages: resinols and tetrahydrofurans $\left(\beta-\beta^{\prime}\right)$, phenylcoumarans $\left(\beta-5^{\prime}\right)$, and spirodienones $\left(\beta-1^{\prime}\right)$. The presence of a tetrahydrofuran structure formed from the $\beta-\beta^{\prime}$ homocoupling of two $\gamma$-acylated monolignols, presumably two $\gamma$-p-coumaroylated sinapyl alcohols, was observed in significant amounts, being especially abundant in the pith 

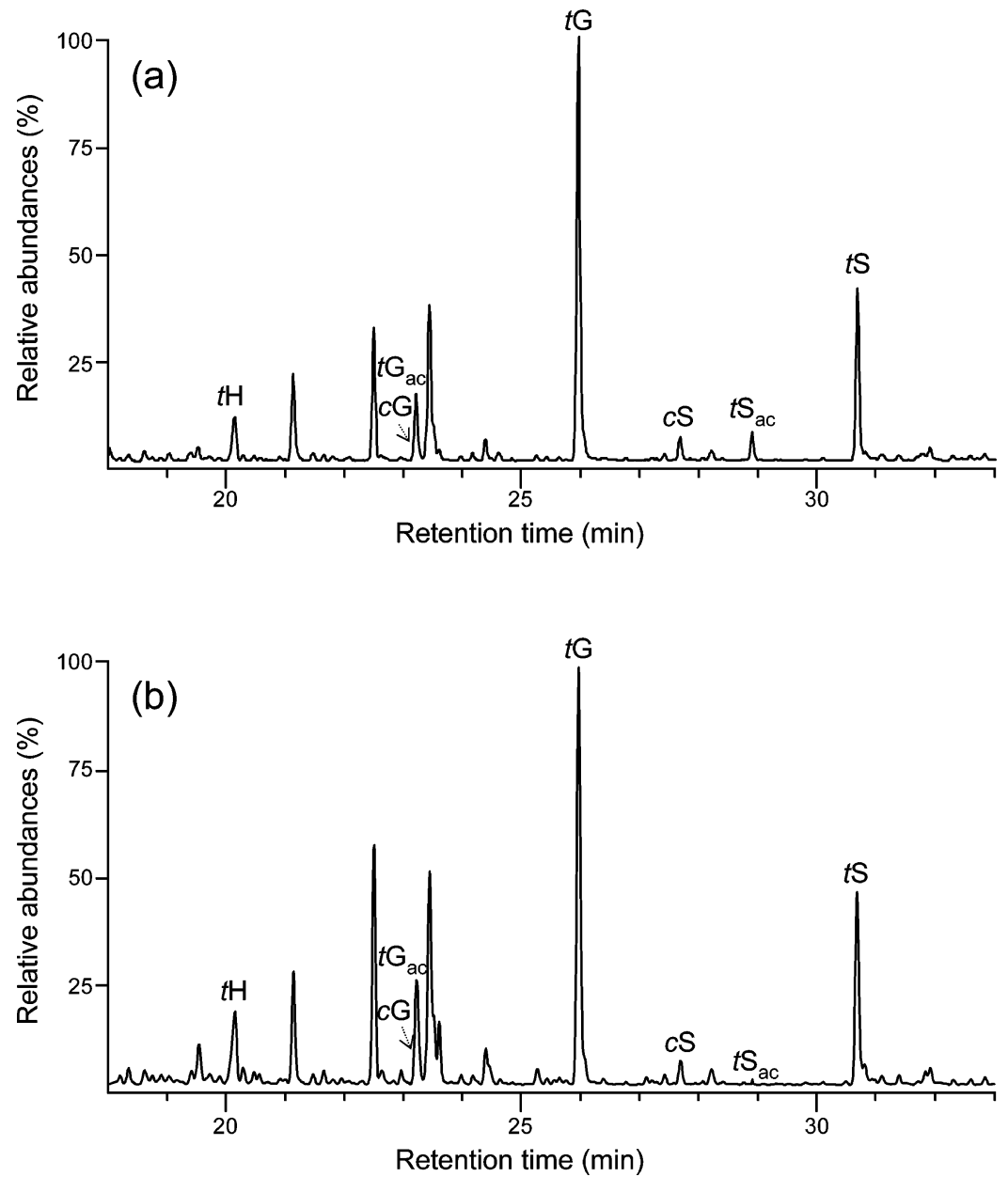

Figure 7. Chromatograms of the DFRC' degradation products from MWLs isolated from elephant grass (P. purpureum) cortex (a) and pith (b). cG, $t \mathrm{G}, c \mathrm{~S}$ and $t \mathrm{~S}$ are the normal cis- and trans-coniferyl and sinapyl alcohol (guaiacyl and syringyl) monomers (as their propionylated derivatives). $c \mathrm{G}_{\mathrm{ac}}$ $t \mathrm{G}_{\mathrm{ac}}, c \mathrm{~S}_{\mathrm{ac}}$ and $t \mathrm{~S}_{\mathrm{ac}}$ are the originally (natively) $\gamma$-acetylated cis- and trans-coniferyl and sinapyl alcohol (guaiacyl and syringyl) monomers (as their propionylated derivatives).

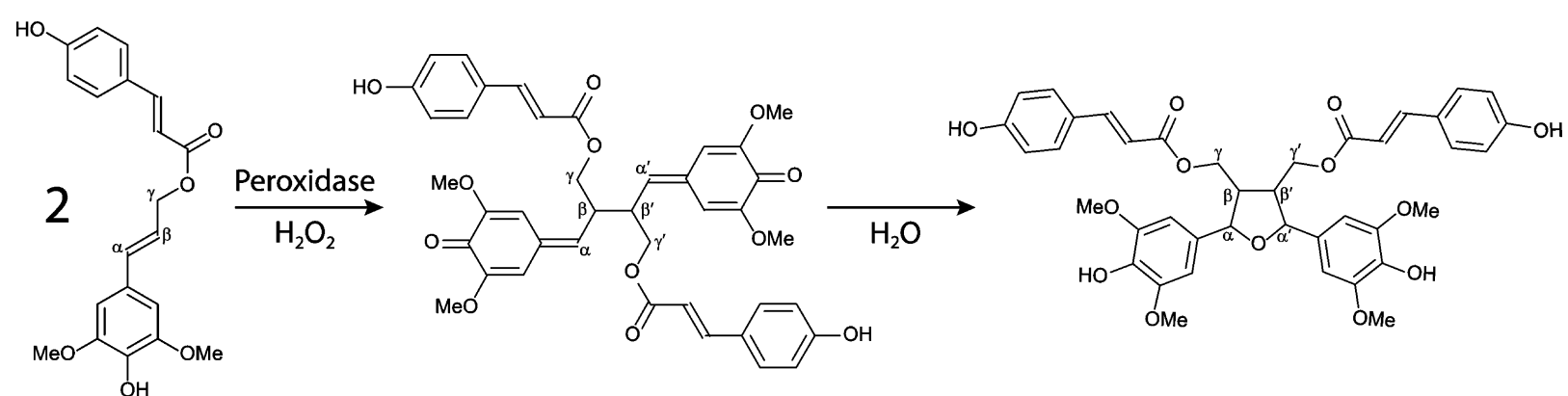

Figure 8. Pathway for the $\beta-\beta^{\prime}$ homocoupling of two sinapyl $p$-coumarate monolignol conjugates producing the tetrahydrofuran structure $\mathbf{C}^{\prime}$ observed in the HSQC spectra with a $\beta-\beta^{\prime}$ linkage and $p$-coumarate groups acylating both $\gamma$-OHs.

(5\% of all interunit linkages), corresponding with its higher degree of $\gamma$-acylation. The presence of these tetrahydrofuran substructures in the lignin polymer is indicative of the occurrence of $p$-coumaroylated monolignol conjugates that participate in coupling and cross-coupling reactions during elephant grass lignification.

\section{AUTHOR INFORMATION}

\section{Corresponding Author}

*Tel: +34-95-4624711. Fax: +34-95-4624002. E-mail: delrio@ irnase.csic.es.

\section{Funding}

This study has been funded by the Spanish project AGL2011-25379, the CSIC project 201040E075 and the EU-project LIGNODECO (KBBE-244362). John Ralph was funded in part by the DOE Great Lakes Bioenergy Research Center (DOE Office of Science BER DE-FC02-07ER64494). Jorge Rencoret thanks the CSIC for a JAE-DOC contract of the program "Junta para la Ampliación de Estudios" cofinanced by Fondo Social Europeo (FSE), and Pepijn Prinsen thanks the Spanish MICINN for a FPI fellowship.

\section{Notes}

The authors declare no competing financial interest. 


\section{ACKNOWLEDGMENTS}

We thank Prof. Jorge L. Colodette and Prof. Jose L. Gomide (Univ. of Viçosa, Brazil) for providing the elephant grass. We also thank Dr. Yuki Tobimatsu (Univ. Wisconsin, Madison) for performing the GPC analyses, Dr. Fachuang Lu for help and advice on DFRC methods and GC-MS of the products, and Hoon Kim for providing the method and most of the assignments in his gel-state NMR method.

\section{REFERENCES}

(1) Himmel, M. E. Biomass Recalcitrance. Deconstructing the Plant Cell Wall for Bioenergy; Blackwell: Oxford, U.K., 2008.

(2) Zhang, Y. H. P. Reviving the carbohydrate economy via multiproduct lignocellulose biorefineries. J. Ind. Microbiol. Biotechnol. 2008, $35,367-375$.

(3) Schank, S. C.; Chynoweth, D. P.; Turick, C. E.; Mendoza, P. E. Napiergrass genotypes and plant parts for biomass energy. Biomass Bioenergy 1993, 4, 1-7.

(4) Woodard, K. R.; Prine, G. M. Dry matter accumulation of elephant grass, energy cane and elephant millet in a subtropical climate. Crop Sci. 1993, 33, 818-824.

(5) Somerville, C.; Youngs, H.; Taylor, C.; Davis, S. C.; Long, S. P. Feedstocks for lignocellulosic biofuels. Science 2010, 329, 790-792.

(6) Higuchi, T. Biochemistry and Molecular Biology of Wood; Springer Verlag: London, U.K., 1997.

(7) Boerjan, W.; Ralph, J.; Baucher, M. Lignin biosynthesis. Annu. Rev. Plant Biol. 2003, 54, 519-546.

(8) Ralph, J.; Lundquist, K.; Brunow, G.; Lu, F.; Kim, H.; Schatz, P. F.; Marita, J. M.; Hatfield, R. D.; Ralph, S. A.; Christensen, J. H.; Boerjan, W. Lignins: Natural polymers from oxidative coupling of 4-hydroxyphenylpropanoids. Phytochem. Rev. 2004, 3, 29-60.

(9) Xie, X. -M.; Zhang, X. -Q.; Dong, Z. -X.; Guo, H. -R. Dynamic changes of lignin contents of MT-1 elephant grass and its closely related cultivars. Biomass Bioenergy 2011, 35, 1732-1738.

(10) Faix, O.; Meier, D.; Fortmann, I. Thermal degradation products of wood. A collection of electron-impact (EI) mass spectra of monomeric lignin derived products. Holz Roh-Werkst. 1990, 48, 351354.

(11) Ralph, J.; Hatfield, R. D. Pyrolysis-GC/MS characterization of forage materials. J. Agric. Food Chem. 1991, 39, 1426-1437.

(12) del Río, J. C.; Gutiérrez, A.; Martínez, A. T. Identifying acetylated lignin units in non-wood fibers using pyrolysis-gas chromatography/mass spectrometry. Rapid Commun. Mass Spectrom. 2004, 18, 1181-1185.

(13) del Río, J. C.; Gutiérrez, A.; Rodríguez, I. M.; Ibarra, D.; Martínez, A. T. Composition of non-woody plant lignins and cinnamic acids by Py-GC/MS, Py/TMAH and FT-IR. J. Anal. Appl. Pyrolysis 2007, 79, 39-46.

(14) del Río, J. C.; Martín, F.; González-Vila, F. J. Thermally assisted hydrolysis and alkylation as a novel pyrolytic approach for the structural characterization of natural biopolymers and geomacromolecules. Trends Anal. Chem. 1996, 15, 70-79.

(15) Liitiä, T. M.; Maunu, S. L.; Hortling, B.; Toikka, M.; Kilpeläinen, I. Analysis of technical lignins by two- and three-dimensional NMR spectroscopy. J. Agric. Food Chem. 2003, 51, 2136-2143.

(16) Capanema, E. A.; Balakshin, M. Y.; Kadla, J. F. A comprehensive approach for quantitative lignin characterization by NMR spectroscopy. J. Agric. Food Chem. 2004, 52, 1850-1860.

(17) Capanema, E. A.; Balakshin, M. Y.; Kadla, J. F. Quantitative characterization of a hardwood milled wood lignin by nuclear magnetic resonance spectroscopy. J. Agric. Food Chem. 2005, 53, 9639-9649.

(18) Ralph, J.; Marita, J. M.; Ralph, S. A.; Hatfield, R. D.; Lu, F.; Ede, R. M.; Peng, J.; Quideau, S.; Helm, R. F.; Grabber, J. H.; Kim, H.; Jimenez-Monteon, G.; Zhang, Y.; Jung, H. -J. G.; Landucci, L. L.; MacKay, J. J.; Sederoff, R. R.; Chapple, C.; Boudet, A. M. Solutionstate NMR of lignin. In Advances in lignocellulosics characterization, Argyropoulos, D. S., Ed.; Tappi Press: Atlanta, 1999; pp 55-108.
(19) Ralph, S. A.; Ralph, J.; Landucci, L. NMR database of lignin and cell wall model compounds; US Forest Prod. Lab.: One Gifford Pinchot Dr., Madison, WI 53705 (http://ars.usda.gov/Services/docs. htm?docid=10491), (accessed: January 2009), 2004.

(20) Ralph, J.; Landucci, L. L. NMR of lignins. In Lignin and Lignans; Advances in Chemistry; Heitner, C., Dimmel, D. R., Schmidt, J. A., Eds.; CRC Press (Taylor \& Francis Group): Boca Raton, FL, 2010; pp 137-234.

(21) Kim, H.; Ralph, J.; Akiyama, T. Solution-state 2D NMR of ballmilled plant cell-wall gels in DMSO-d $\mathrm{d}_{6}$. Bioenergy Res. 2008, 1, 56-66.

(22) Martínez, A. T.; Rencoret, J.; Marques, G.; Gutiérrez, A.; Ibarra, D.; Jiménez-Barbero, J.; del Río, J. C. Monolignol acylation and lignin structure in some nonwoody plants: A 2D-NMR study. Phytochemistry 2008, 69, 2831-2843.

(23) Rencoret, J.; Marques, G.; Gutiérrez, A.; Ibarra, D.; Li, J.; Gellerstedt, G.; Santos, J. I.; Jiménez-Barbero, J.; Martínez, A. T.; del Río, J. C. Structural characterization of milled wood lignin from different eucalypt species. Holzforschung 2008, 62, 514-526.

(24) Rencoret, J.; Marques, G.; Gutiérrez, A.; Nieto, L.; Santos, J. I.; Jiménez-Barbero, J.; Martínez, A. T.; del Río, J. C. HSQC-NMR analysis of lignin in woody (Eucalyptus globulus and Picea abies) and non-woody (Agave sisalana) ball-milled plant materials at the gel state. Holzforschung 2009, 63, 691-698.

(25) Rencoret, J.; Marques, G.; Gutiérrez, A.; Nieto, L.; JiménezBarbero, J.; Martínez, A. T.; del Río, J. C. Isolation and structural characterization of the milled wood lignin from Paulownia fortunei wood. Ind. Crops Prod. 2009, 30, 137-143.

(26) del Río, J. C.; Rencoret, J.; Marques, G.; Gutiérrez, A.; Ibarra, D.; Santos, J. I.; Jiménez-Barbero, J.; Zhang, L.; Martínez, A. T. Highly acylated (acetylated and/or p-coumaroylated) native lignins from diverse herbaceous plants. J. Agric. Food Chem. 2008, 56, 9525-9534.

(27) del Río, J. C.; Rencoret, J.; Marques, G.; Li, J.; Gellerstedt, G.; Jiménez-Barbero, J.; Martínez, A. T.; Gutiérrez, A. Structural characterization of the lignin from jute (Corchorus capsularis) fibers. J. Agric. Food Chem. 2009, 57, 10271-10281.

(28) del Río, J. C.; Rencoret, J.; Gutiérrez, A.; Nieto, L.; JiménezBarbero, J.; Martínez, A. T. Structural characterization of guaiacyl-rich lignins in flax (Linum usitatissimum) fibers and shives. J. Agric. Food Chem. 2011, 59, 11088-11099.

(29) Rencoret, J.; Gutiérrez, A.; Nieto, L.; Jiménez-Barbero, J.; Faulds, C. B.; Kim, H.; Ralph, J.; Martínez, A. T.; del Río, J. C. Lignin composition and structure in young versus adult Eucalyptus globulus plants. Plant Physiol. 2011, 155, 667-682.

(30) Lu, F.; Ralph, J. Derivatization followed by reductive cleavage (DFRC method), a new method for lignin analysis: protocol for analysis of DFRC monomers. J. Agric. Food Chem. 1997, 45, 25902592.

(31) Lu, F.; Ralph, J. The DFRC method for lignin analysis. Part 1. A new method for $\beta$-aryl ether cleavage: lignin model studies. J. Agric. Food Chem. 1997, 45, 4655-4660.

(32) Lu, F.; Ralph, J. The DFRC method for lignin analysis. 2. Monomers from isolated lignin. J. Agric. Food Chem. 1998, 46, 547552.

(33) Lu, F.; Ralph, J. Detection and determination of pcoumaroylated units in lignins. J. Agric. Food Chem. 1999, 47, 19881992.

(34) Ralph, J.; Lu, F. The DFRC method for lignin analysis. 6. A simple modification for identifying natural acetates in lignin. J. Agric. Food Chem. 1998, 46, 4616-4619.

(35) del Río, J. C.; Marques, G.; Rencoret, J.; Martínez, A. T.; Gutiérrez, A. Occurrence of naturally acetylated lignin units. J. Agric. Food Chem. 2007, 55, 5461-5468.

(36) Tappi Test Methods 2004-2005, Tappi Press, Norcoss, GA 30092, USA, 2004.

(37) Darwill, A.; McNeil, M.; Albersheim, P.; Delmer, D. The primary cell-walls of flowering plants. In The Biochemistry of Plants; Tolbert, N., Ed.; Academic Press: New York, 1980; pp 91-162.

(38) Browning, B. L. Methods of Wood Chemistry; Wiley-Interscience Publishers: New York, 1967; Vol. II. 
(39) Björkman, A. Studies on finely divided wood. Part I. Extraction of lignin with neutral solvents. Sven. Papperstidn. 1956, 59, 477-485.

(40) Baumberger, S.; Fasching, M.; Gellerstedt, G.; Gosselink, R.; Hortling, B.; Li, J.; Saake, B.; de Jong, E. Molar mass determination of lignins by size-exclusion chromatography: towards standardisation of the method. Holzforschung 2007, 61, 459-468.

(41) Grabber, J. H.; Quideau, S.; Ralph, J. p-Coumaroylated syringyl units in maize lignin: Implications for $\beta$-ether cleavage by thioacidolysis. Phytochemistry 1996, 43, 1189-1194.

(42) Grabber, J. H.; Ralph, J.; Hatfield, R. D. Cross-linking of maize walls by ferulate dimerization and incorporation into lignin. J. Agric. Food Chem. 2000, 48, 6106-6113.

(43) Grabber, J. H.; Lu, F. Formation of syringyl-rich lignins in maize as influenced by feruloylated xylans and p-coumaroylated monolignols. Planta 2007, 226, 741-751.

(44) Lam, T. B. T.; Iiyama, K.; Stone, B. A. Cinnamic acid bridges between cell wall polymers in wheat and phalaris intemodes. Phytochemistry 1992, 31, 1179-1183.

(45) Sun, R. -C.; Sun, X. -F.; Zhang, S. -H. Quantitative determination of hydroxycinnamic acids in wheat, rice, rye, and barley straws, maize stems, oil palm frond fiber, and fast-growing poplar wood. J. Agric. Food Chem. 2001, 49, 5122-5129.

(46) Sun, R. -C.; Sun, X. F.; Wang, S. Q.; Zhu, W.; Wang, X. Y. Ester and ether linkages between hydroxycinnamic acids and lignins from wheat, rice, rye, and barley straws, maize stems, and fast-growing poplar wood. Ind. Crop. Prod. 2002, 15, 179-188.

(47) Hatfield, R. D.; Marita, J. M.; Frost, K.; Grabber, J.; Ralph, J.; Lu, F.; Kim, H. Grass lignin acylation: p-coumaroyl transferase activity and cell wall characteristics of C3 and C4 grasses. Planta 2009, 229, 12531267.

(48) Ralph, J. Hydroxycinnamates in lignification. Phytochem. Rev. 2010, 9, 65-83.

(49) Martín, F.; del Río, J. C.; González-Vila, F. J.; Verdejo, T. Thermally assisted hydrolysis and alkylation of lignins in the presence of tetra-alkylammonium hydroxides. J. Anal. Appl. Pyrolysis 1995, 35, $1-13$.

(50) del Río, J. C.; McKinney, D. E.; Knicker, H.; Nanny, M. A.; Minard, R. D.; Hatcher, P. G. Structural characterization of bio- and geo-macromolecules by off-line thermochemolysis with tetramethylammonium hydroxide. J. Chromatogr., A 1998, 823, 433-448.

(51) Ralph, J.; Hatfield, R. D.; Quideau, S.; Helm, R. F.; Grabber, J. H.; Jung, H. -J. G. Pathway of p-coumaric acid incorporation into maize lignin as revealed by NMR. J. Am. Chem. Soc. 1994, 116, 94489456.

(52) Crestini, C.; Argyropoulos, D. S. Structural analysis of wheat straw lignin by quantitative ${ }^{31} \mathrm{P}$ and $2 \mathrm{D}$ NMR spectroscopy. The occurrence of ester bonds and $\alpha$-O-4 substructures. J. Agric. Food Chem. 1997, 45, 1212-1219.

(53) Rencoret, J.; del Río, J. C.; Gutiérrez, A.; Martínez, A. T.; Li, S.; Parkås, J.; Lundquist, $\mathrm{K}$. Origin of the acetylated structures present in white birch (Betula pendula Roth) milled wood lignin. Wood Sci. Technol. 2012, 46, 459-471.

(54) Lu, F.; Ralph, J. Novel $\beta-\beta$ structures in lignins incorporating acylated monolignols. Appita 2005, 233-237.

(55) Lu, F.; Ralph, J. Novel tetrahydrofuran structures derived from $\beta-\beta$-coupling reactions involving sinapyl acetates in kenaf lignins. Org. Biomol. Chem. 2008, 6, 3681-3694.

(56) Fry, S. C.; Willis, S.; Paterson, A. Intraprotoplasmic and walllocalised formation of arabinoxylan-bound diferulates and larger ferulate coupling-products in maize cell-suspension cultures. Planta 2000, 211, 679-692.

(57) Helm, R. F.; Ralph, J. Lignin-hydroxycinnamoyl model compounds related to forage cell wall structure. 2. Ester-linked structures. J. Agric. Food Chem. 1993, 41, 570-576.

(58) Lu, F.; Ralph, J. Preliminary evidence for sinapyl acetate as a lignin monomer in kenaf. Chem. Commun. 2002, 90-91.

(59) Ralph, J. An unusual lignin from kenaf. J. Nat. Prod. 1996, 59, 341-342.
(60) Ralph, J. What makes a good monolignol substitute? In The Science and Lore of the Plant Cell Wall Biosynthesis, Structure and Function; Hayashi, T., Ed.; Universal Publishers (BrownWalker Press): Boca Raton, FL, 2006; pp 285-293.

(61) Withers, S.; Lu, F.; Kim, H.; Zhu, Y.; Ralph, J.; Wilkerson, C. G. Identification of a grass-specific enzyme that acylates monolignols with p-coumarate. J. Biol. Chem. 2012, 287, 8347-8355. 